Commodity Traders in a Storm: Financialization, Corporate Power and Ecological Crisis

Joseph Baines

Department of European and International Studies, King's College London, London, United Kingdom

Sandy Brian Hager

Department of International Politics, City, University of London, London, United Kingdom, (Sandy.Hager@city.ac.uk)

This is a pre-preprint of an article accepted for publication in Review of International Political Economy

https://doi.org/10.1080/09692290.2021.1872039 


\title{
Commodity Traders in a Storm: Financialization, Corporate Power and Ecological Crisis
}

\begin{abstract}
Commodity trading firms occupy a central position in global supply chains and their activities have been associated with financial instability, social upheaval and manifold forms of ecological devastation. This paper examines these companies in the context of debates regarding corporate financialization. We find that since the 2003-2011 commodity boom, trading firms have become less financialized in terms of the source of their profits as they have shifted away from financial activities. However, they have become more financialized in terms of the destination of profits, with dividend and share repurchase commitments reaching new heights after 2015. In view of this finding, we inquire into whether trading firms' growing commitment to shareholder payouts will encourage them to continue to prioritize short-term returns, or whether instead these firms' linkages to financial markets will lend clout to financial activists concerned by the long-term environmental and social consequences of their operations. Ultimately, we find several sources of commodity trader resilience which insulate them from shareholder resolutions and divestment campaigns aimed at curbing ecological destruction and human rights abuses in their supply chains. We accordingly suggest that pressures from activist investors must be complemented with more wide-ranging efforts to defend living systems across the planet.
\end{abstract}

Keywords: commodity trading firms; ecological crisis; financialization; corporate power; shareholder value; financial activism

\section{Introduction}

The titles of journalistic books on multinational corporations tend towards hyperbole. Such is the case with The Secret Club that Runs the World, American reporter Kate Kelly's (2014) investigation into the world of commodity trading. In reality, the major commodity trading firms are not a secret club, but they are shadowy entities that shy away from the spotlight. They do not run the world, but they do occupy a central position within contemporary capitalism. 
The poetic license of Kelly's title should not detract from the key insight: the commodity traders are among the most important firms in the world, and yet most people have never heard of them.

What are commodity trading firms? And why do they matter? At the most fundamental level, commodity trading firms are the main intermediaries within global commodity supply chains (Chalmin, 1987). Through their extensive transportation activities, they connect the producers and the users of raw materials across space. Through their storage facilities, they mediate the discontinuities of production and consumption across time. Through their processing capabilities, they transform raw materials into secondary products. And through their derivatives operations, they manage their exposure to the price fluctuations of the underlying commodities that they trade (Pirrong, 2014). In short, the commodity traders control the channels through which commodities pass from producers to manufacturers, and they operate at the interstices of physical and financial markets.

A brief glance at market share data reveals the centrality of these multinational giants in the supply of essential raw materials. The four largest agricultural commodity traders - Archer Daniels Midland (ADM), Bunge, Cargill and Louis Dreyfus - control between $75 \%$ and 90\% of the international grain trade; just three commodity traders - Vitol, Glencore and Trafigura handle equivalent to half of OPEC's total oil output; and Glencore alone accounts for $55 \%$ of the global zinc market and $36 \%$ of the global copper market, while Wilmar accounts for $45 \%$ of the world trade in palm oil (Lawrence, 2011; Schneyer, 2011; Sheppard \& Hume, 2017; Stringer, 2014). Over the past decade, the annual revenues of the major commodity trading firms have been comparable to, and in some instances even exceeded, those of the Wall Street banks as well as the major mining and oil companies (see Figure A1 in the Appendix). 
Along with staggering financial clout, the commodity traders have also been mired in controversy. They have been accused of promoting deforestation and other forms of ecological damage (Amazon Watch, 2019; Amnesty International, 2016). There are concerns regarding their role in marketing commodities extracted or harvested through forced labour, including child labour (Braunschweig et al., 2019). They have been entangled in multiple corruption cases (Berne Declaration, 2012). And finally, there are ongoing concerns regarding their alleged manipulation of physical markets as well as the potentially destabilizing impacts of their speculative activities in derivatives markets (Oxfam, 2012a; The Economist, 2014). The fact that commodity traders are embroiled in scandal and controversy is nothing new (see Ammann, 2011; Morgan, 1979). But concerns regarding their operations have become more widespread against the backdrop of overarching dysfunctions in the global economy over the past five decades which have generated increasing inequality, greater financial instability, and accelerating ecological breakdown (Dobler \& Kesselring, 2019; Elsby, 2020).

A small but growing body of literature adopts the concept of financialization as a common theoretical point of departure to explore the business practices of the commodity trading firms (Clapp \& Isakson, 2018; Isakson, 2014; Salerno, 2017). According to existing accounts, financialization has encouraged a short-term outlook among the commodity traders with the result that long-term social stability and ecological integrity, especially in the Global South, are heavily discounted in favour of generating immediate financial returns (McMichael, 2012). A key theme in this literature is that the concept of financialization helps to reveal how and why commodity trading firms have embraced short-term, risky behaviour that boosts their profits at the expense of workers, customers, and the communities in which they operate (Clapp \& Helleiner, 2012a). Notwithstanding all the impressive insights of this body of research, there has not yet been a systematic mapping of financialization for all of the major commodity traders. Thus, the purpose of this article is to fill these gaps in our knowledge, offering the first 
comprehensive account of the commodity trading firms in the context of debates regarding financialization and corporate involvement in social and ecological harms.

In our analysis we explore the two main facets of corporate financialization emphasized in the literature: the financialization of accumulation and the rise of shareholder value norms (Van der Zwan, 2014). When taken as a whole, we find incongruence between the two facets of financialization as they apply to the commodity trading firms. In terms of the first facet of financialization (accumulation), the commodity traders have actually become less financialized since the end of the 2003-2011 commodity boom as they have shifted their focus away from ancillary financial activities towards their core processing and merchandising operations. But in terms of the second facet of financialization (shareholder value), the major commodity traders have become more financialized with dividend and share repurchase commitments reaching higher levels between 2015 and 2019 than in any other period for which we have data. These findings, we argue, significantly complicate the commonly-held view among scholars that the maximization of shareholder value and the financialization of accumulation run in parallel (see also Rabinovich, 2019; Soener, 2020).

Having mapped the changes undertaken by the major commodity traders, we inquire into whether trading firms' growing commitment to shareholder value will encourage them to continue prioritizing short-term returns, or whether instead these firms' linkages to financial markets can be leveraged by financial activists concerned with the long-term environmental and social consequences of their activities. This important line of inquiry has been thus far neglected. The existing literature has documented how, in the realm of public governance, commodity traders have successfully pushed back against regulatory initiatives to curb potentially destabilizing derivatives trading in the wake of the global financial crisis and commodity price spikes between 2007 and 2011 (Baines, 2017; Helleiner, 2018; Pagliari, 2018). Yet much less attention has been given to the role of different forms of financial activism, such 
as shareholder resolutions and divestment campaigns, in driving improvements in the private governance of these firms. Exploring the limits and possibilities of these strategies allows us to better grasp the potential paradoxes of financialization. While some facets of financialization may fuel the destructive behaviour of commodity trading firms, it may also open up ways for shareholders and creditors to pressure companies to reign in that destructive behaviour.

Our findings point to several sources of commodity trader resilience in the face of activist investor pressures to reduce their harmful social and ecological impacts. In particular, the predominance of private ownership among many of the commodity trading firms shields them from equity divestment campaigns or shareholder resolutions. Shareholder voting data indicate that shareholder resolutions aimed at environmental and social governance (ESG) improvements among the commodity trading firms are few and far between. Furthermore, voting patterns of the major asset management firms in resolutions within the commodity sector from 2013-2019 indicate that they almost always vote in favour of management resolutions seeking approval for dividend payouts and stock buybacks, and they almost invariably vote against shareholder resolutions aimed at improving environmental and social governance. Our analysis also shows that the threat of debt divestment is attenuated by the dispersion of holdings in the commodity traders' bonds as well as company deleveraging and shadow banking activities. Given the weakness of these threats of financial activism, commodity trading firms may not feel significant pressure to strengthen their ESG commitments.

Overall, then, the article makes two key contributions to the existing literature. Firstly, it advances a more detailed and nuanced understanding of the variegated financialization of the major commodity traders, by showing how these firms have become less financialized in terms of their accumulation practices, but more financialized in terms of their shareholder value commitments. Secondly, it offers the first assessment of the extent to which, in this context of 
variegated financialization, financial activism can push the commodity traders to reverse the social and ecological harms of their operations. The remainder of the article develops as follows. In the second section, we review the existing literature on corporate financialization in the commodity sector. In the third section, we set the stage for our empirical mapping of financialization metrics by discussing our case selection and presenting data on the ownership structures, financing sources and profitability of the major commodity traders. In the fourth and fifth sections we empirically map the financialization metrics of commodity trading firms, examining the financialization of accumulation and the rise of shareholder value norms, respectively. In the sixth section, we assess the extent to which the mobilization of financial activist pressures can push these firms to operate in ways concordant with ecological restoration and broader societal interests. In the conclusion we summarize our findings and argue in favour of multi-faceted efforts to confront the power of diverse and complex entities like the commodity trading firms.

\section{Financialization and Its Discontents in the Commodity Sector}

The literature on financialization has expanded rapidly in recent decades. Commonly defined as the growing role of financial motives, financial markets and financial institutions in the global economy (Epstein, 2005, p. 3), the concept's proliferation largely stems from its perceived potential in capturing key shifts in global capitalism since the 1970s (Davis \& Kim, 2015). With regard to corporate financialization in the commodity sector, two key approaches can be discerned, which broadly mirror two of the main approaches identified in the literature on corporate financialization at large (Van der Zwan, 2014). The first approach in this broader literature conceptualizes financialization as the growth in accumulation via financial activities at both the firm-level and in the broader economy (Stockhammer, 2004; Krippner, 2011). The 
second approach takes financialization to be driven by the ascendancy of shareholder value norms, which has led to corporate downsizing and outsourcing, on the one hand, and increased payments by firms to shareholders via dividends and share repurchases, on the other (Lazonick \& O’Sullivan, 2000; Milberg 2008).

\section{The financialization of accumulation}

Researchers who adopt the first approach to financialization broadly see it as a distinct phase in the history of capitalist accumulation. When it comes to understanding the relations between financialization, ecological degradation and the transformation of commodity markets, Jason Moore's (2015) world-ecology framework has arguably been the most influential. Drawing on the work of Giovanni Arrighi (1994), Moore views capitalist history as an unfolding of alternate waves of material and financial expansion. For Moore, the waves of material expansion hinge on the successful mobilization of the unpaid work of 'Cheap Nature' outside of the commodity system - namely cheap food, labour, energy and raw materials - into the sphere of accumulation. But when Cheap Nature is provisionally exhausted, profitability in productive activities declines and financialization ensues.

According to Moore, phases of financialization, in turn, give way to new waves of imperialism and scientific breakthroughs which reinvigorate the intensified appropriation of Cheap Nature. And these developments propel extended phases of material expansion. However, Moore argues that at this current stage in the history of capitalism, the process of appropriation is nearing an asymptote as myriad phenomena such as the collapse in pollinator populations, the evermore resource-intensive forms of energy extraction, and the destabilization of the world's climate indicate that Cheap Nature is edging towards terminal exhaustion. It is in this context that Moore makes sense of the financialization of the global economy over the last five decades: 
the decline of Cheap Nature has led to diminished profitability in the sphere of production, and this diminished profitability has in turn led to expanded financial accumulation (Moore, 2015). For Moore, financialization is set to continue in the context of accelerating environmental degradation, and may signal a terminal crisis in capitalist profitability. From this perspective, he insists that ' $[\mathrm{g}]$ lobal warming poses a fundamental threat not only to humanity, but, more immediately and directly, to capitalism itself' (Moore, 2015, p. 290).

While Moore offers the most ambitious theorization of the macro-level relationship between environmental degradation and financialization, other contributions provide more specific empirical insights into financial accumulation in the commodity sector. A key theme in this research is that the influx of financial actors in commodity markets may have exacerbated commodity price volatility in ways that have had significant distributional consequences (Baines, 2017; Clapp \& Helleiner, 2012b; Newman, 2009). However, the literature most relevant for our purposes focuses on the commodity trading firms themselves. For example, Philip McMichael (2012) argues that in the context of accumulation crisis, as dramatized by the global financial crash of 2007-08, corporations such as ADM and Cargill sought to boost their profitability by speculating vast sums, on their own account or on behalf of third-party investors, in everything from derivatives to land and biofuels. This analysis is reaffirmed by detailed accounts of the financial activities within ADM, Bunge, Cargill and Louis Dreyfus (Murphy et al., 2012; Salerno, 2017).

Complementing this literature on agricultural commodity trading firms are recent analyses of the largest commodity traders in energy and metal markets. Andreas Goldthau and Llewelyn Hughes (2020) argue that the rise of the major oil traders - Glencore, Vitol and Trafigura - has been coeval with the financialization of the oil sector and the vertical disintegration of oil supply chains since the 1970s. As Goldthau and Hughes (2020, p. 11) contend, this process has led to growing homogenization in the sector, as oil majors' trading activities increasingly 
resemble those of commodity trading firms. The tendency towards homogenization has also been identified in metals markets where the largest physical traders, such as Glencore, established 'trading arms that operated like financial institutions generating substantial financial-trading profits' (Seddon, 2020, p. 543).

Financialization as the rise of shareholder value

Just as there is an emergent literature on the growing role of finance as a source of profits for firms operating in the commodity sector, there are also analyses examining finance as an increasingly important destination for profits through the process of shareholder value maximization (De los Reyes, 2017; Labban, 2014). Reflecting a common view in the literature on corporate financialization that the rise of financialized accumulation and shareholder value maximization are interconnected, Jennifer Clapp and S. Ryan Isakson (2018, p. 443) argue that agri-food firms 'are encouraged by their shareholders to increase their financial activities as a means by which to improve their performance.'

Furthermore, in an analysis of equity holdings in the major agri-food corporations, including ADM and Bunge, Clapp (2019) argues that the considerable share of ownership taken up by the asset management firms may lead these agri-food firms to move their focus away from directly competing in product markets in favour of strategies aimed at boosting sector-wide profitability and returns. Such a shift, Clapp suggests, could come to the detriment of both consumers and farmers who may have to pay more for the products they purchase. It may also have broader social and ecological consequences as firms become locked into enhancing shortterm shareholder returns through deploying existing technologies rather than experimenting with ecologically restorative innovations (Clapp, 2019, p. 623). 
There are also noteworthy analyses of the influence of shareholder value norms in the energy sector. For example, Paul Stevens (2016) argues that a key consequence of the prioritization of shareholder value is that oil companies have increasingly sought to minimize their costs through outsourcing oil extraction to medium-sized firms. Mazen Labban (2014) devotes attention to how this drive to minimize costs and maximize shareholder returns has led to significant layoffs among major oil companies. As Labban (2014, p. 487) argues, beyond outsourcing, mergers and acquisitions along with divestitures have been important vectors of shareholder value maximization as such practices enhance the scope for workforce reductions.

Similar themes appear in the literature on shareholder value maximization in the mining sector where it has been found that institutional investors have pressured mining companies to increase shareholder returns (De los Reyes, 2017, pp. 252-254). During the boom in minerals prices from 2003 to 2011, these pressures led mining firms to increase capital investment, via mergers and acquisitions as well as greenfield and brownfield projects, in order to intensify production - frequently in a manner that caused significant disruption to surrounding communities (Bowman, 2018). This surging investment also led to more instability in the mining sector itself once firms found themselves overcommitted to mining activities during the subsequent slump in prices. In this context, there has been a heightened focus on costminimization and divestiture to sustain shareholder payouts (De los Reyes, 2017, pp. 258-260), leading to a renewed drive to curb wages, lay-off workers and close the most labour-intensive mines (Bowman, 2018; Parker et al., 2017). The main contribution of this work is that it illuminates the interplay between growing commitments to shareholder value maximization, on the one hand, and the cyclicality of commodity markets, on the other. As this research shows, the ascent of shareholder value norms is not always concordant with an expansion of financial activity. In certain periods, firms may instead rapidly expand production to boost shareholder 
returns, but often in ways that exacerbate financial fragility, social inequality and environmental destruction.

To sum up, five key claims can be distilled from the existing literature. Firstly, from a worldecological perspective, financialization is set to continue in the context of accelerating environmental degradation, and may signal a terminal crisis in capitalist profitability. Secondly, in the context of the financialization of commodity markets, commodity trading firms have converged with other companies towards a financialized business model. Thirdly, shareholder value maximization is concordant with increased accumulation via financial activities as pressures to deliver shareholder returns encourage firms to engage in financial investment to boost profits. Fourthly, while fixed investment may increase during cyclical upswings in commodity prices, ongoing pressures to cut costs via outsourcing, layoffs and divestitures become more accentuated during cyclical downswings in commodity prices. Finally, the predominance of asset management companies in equity ownership reinforces commodity firms' commitment to short-term returns over long-term social and environmental concerns.

\section{Who are the Major Commodity Trading Firms?}

So far, we have identified key claims in the existing literature on the financialization of commodity markets and trading firms. This literature raises important questions that we seek to address. Firstly, in what respects - if any - are the commodity trading firms becoming increasingly financialized? Is it through expanding financial activities, through distributing larger shares of company earnings to shareholders, or is it both? Secondly, what is the relationship between the financialization of accumulation and the maximization of shareholder value among the commodity trading firms? Thirdly, how does this relationship change in the context of commodity price cycles and concomitant shifts in company profitability? Fourthly, 
can financial activists successfully push commodity traders to reverse the ecological and social harms of their operations, or does corporate financialization inexorably lead firms to prioritize short-term financial returns over long-term social stability and ecological integrity?

The existing scholarship offers important pointers in navigating these questions. However, it has not yet provided definitive answers. One reason for this is that much of the literature on the financialization of the commodity sector examines it from a macroscopic perspective; and the literature that does examine firm-level financialization either looks at companies adjacent to commodity trading firms in supply chains, such as mining or oil companies, or it looks at one particular subset of trading firms, such as the agricultural commodity traders or oil trading firms. Another reason for the uncertainty regarding the commodity trading firms' business trajectories arises from the perceived paucity of data, especially with respect to the privatelyheld trading houses (Isakson, 2015, p. 762; Murphy et al., 2012, p. 24). This has meant that no existing scholarship has gauged the degree to which the commodity trading firms have invested in financial assets and generated profits from financial activities, nor has it established the extent to which commodity trading firms have committed themselves to maximizing shareholder value. ${ }^{1}$

In light of gaps in existing knowledge, we draw on data and company filings deposited in five key databases - Bloomberg Professional, Compustat, Orbis, Thomson Reuters Eikon and Thomson Reuters SDC - to provide the most comprehensive mapping of the financialization of the major commodity traders to date. Rather than focusing on just one sectoral subset of the commodity trading firms, our study departs from existing contributions by examining all the major commodity trading firms to better understand the specific dynamics of financialization as it pertains to each and every commodity sector, from agriculture, to metals and energy. 
Specifically, we focus on the ten largest commodity trading firms ranked by revenues - ADM, Bunge, Cargill, COFCO, Glencore, Louis Dreyfus, Mercuria, Trafigura, Vitol and Wilmar over a three-decade period spanning from the beginning of the 1990s to the end of the 2010s. We are confined to this time-period due to data constraints. Although we have relevant data on ADM going all the way back to 1950, data for the other firms only become accessible from 1993 onwards. Despite these constraints, the original dataset we have compiled does offer the advantage of allowing us to trace shifts in the business models of these firms before, during and after the 2003-2011 commodity boom.

The rationale for our choice of firms is more complex. In some respects, we are again circumscribed by limited data availability. For example, two firms which trade significant quantities of oil - Koch Industries and Gunvor - are so secretive that they rarely publish data on their net income, let alone more specific information directly related to their financial activities. Beyond these issues of data availability, we face selection dilemmas for firms which do publish relevant data as the boundaries of the commodity trading business are themselves blurred. Some of the major corporations described as commodity trading firms - such as Cargill and Louis Dreyfus - have distanced themselves from this characterization, and now increasingly identify themselves as 'supply chain managers' operating both upstream in the production of primary commodities, and downstream in the manufacture of consumer and industrial goods (Clapp, 2015; Kingsman, 2019). Another firm included in the dataset Glencore - has departed even more radically from the traditional trading model to become an industrial conglomerate heavily engaged in mining activities. The Japanese general trading companies - the sōgo shōsha - are also of great importance in supplying commodities, especially in East Asia (see Figure A1). Nonetheless, they do not form part of our analysis because much of their revenue is generated from trading products beyond primary and 
secondary commodity markets: from microchips, to construction machinery, to aircraft (Hiraga, 2018). To complicate matters further, some companies that undertake significant commodity trading operations are subsidiaries within major mining and oil corporations, as well as banks (Omarova, 2013). In short, diversification and conglomeration mean that there is no precise way of delineating the major commodity traders. We therefore include the entities that either self-identify or are commonly identified - by governments, NGOs, the financial press and academic researchers - as commodity trading firms.

With this in mind, Table 1 provides further information on the ten companies, including data on their revenues, their principal asset class, their ownership structure, and their major shareholders, bondholders and loan underwriters. The table clearly shows the diverse financial ties of each commodity trading firm. In terms of equity holdings, COFCO is a Chinese stateowned enterprise. In contrast, ADM and Bunge's key equity holders include US-headquartered asset management companies such as BlackRock and Vanguard (see also Clapp, 2019); whereas Glencore's are the sovereign wealth fund, the Qatari Investment Agency, as well as the major asset management companies. Wilmar has a similarly diverse range of equity holders - from another commodity trader in ADM, to the extended family of the company's co-founder and chairman, Kuok Khoon Hong. There is also considerable diversity among the private trading houses. The equity of Mercuria, Trafigura and Vitol Group is principally held by their senior employees, while the ownership structures of Cargill and Louis Dreyfus are primarily organized on familial lines. Cargill is presently controlled by around 100 descendants of William Wallace Cargill, the man who established the company over 150 years ago. There are currently more billionaires in this dynasty, 14 in total, than in any other family in the world (Forbes, 2016). In contrast, the equity of Louis Dreyfus is concentrated in the hands of just one 


\begin{tabular}{|c|c|c|c|c|c|c|}
\hline & $\begin{array}{l}\text { Revenues } \\
2019 \\
\text { (US\$ bn) }\end{array}$ & $\begin{array}{l}\text { Principal } \\
\text { asset } \\
\text { class }\end{array}$ & $\begin{array}{l}\text { Ownership } \\
\text { structure } \\
\text { (location of } \\
\text { headquarters) }\end{array}$ & $\begin{array}{l}\text { Leading shareholders } \\
\text { (percentage of shares } \\
\text { outstanding, 2020) }\end{array}$ & $\begin{array}{l}\text { Leading bondholders } \\
\text { (percentage of outstanding } \\
\text { debt, 2020) }\end{array}$ & $\begin{array}{l}\text { Leading loan underwriters } \\
\text { (percentage of total proceeds, } \\
2018-20 \text { ) }\end{array}$ \\
\hline Vitol & 225.0 & Energy & $\begin{array}{l}\text { Private } \\
\text { (Netherlands) }\end{array}$ & $\begin{array}{l}\text { 1. } 350 \text { senior employees }(100 \%) \\
- \\
- \\
- \\
-\end{array}$ & $\begin{array}{l}- \\
- \\
- \\
-\end{array}$ & $\begin{array}{l}\text { 1. DBS Group Holdings }(6.0 \%) \\
=2 . \text { Sumitomo Mitsui }(5.9 \%) \\
=2 . \text { Mitsubishi UFJ }(5.9 \%) \\
\text { 4. HSBC Holdings }(5.2 \%) \\
\text { 5. Mizuho Financial Group }(5.1 \%)\end{array}$ \\
\hline Glencore & 215.1 & $\begin{array}{l}\text { Metals } \\
\text { Energy }\end{array}$ & $\begin{array}{l}\text { Public } \\
\text { (Switzerland) }\end{array}$ & $\begin{array}{l}\text { 1. Qatar Investment Authority } \\
(9.2 \%) \\
\text { 2. Ivan Glasenberg }(9.1 \%) \\
\text { 3. Harris Associates }(5.6 \%) \\
\text { 4. BlackRock Inc. }(5.2 \%) \\
\text { 5. Daniel Maté }(3.4 \%)\end{array}$ & $\begin{array}{l}\text { 1. BlackRock Inc. }(1.2 \%) \\
\text { 2. Baird Financial Group }(0.9 \%) \\
\text { 3. JPMorgan Chase }(0.8 \%) \\
\text { 4. Lord Abbett \& Co. }(0.6 \%) \\
\text { 5. Western Asset Management } \\
(0.5 \%)\end{array}$ & $\begin{array}{l}\text { 1. ING }(7.0 \%) \\
\text { 2. Société Générale }(4.0 \%) \\
=3 . \text { Santander Corp }(3.7 \%) \\
=3 . \text { Deutsche Bank }(3.7 \%) \\
=3 \text {. Credit Agricole }(3.7 \%)\end{array}$ \\
\hline $\begin{array}{l}\text { Trafigura } \\
\text { Beheer }\end{array}$ & 171.5 & $\begin{array}{l}\text { Metals } \\
\text { Energy }\end{array}$ & $\begin{array}{l}\text { Private } \\
\text { (Netherlands) }\end{array}$ & $\begin{array}{l}\text { 1. } 700 \text { senior employees }(100.0 \%) \\
- \\
- \\
- \\
-\end{array}$ & $\begin{array}{l}\text { 1. GAM Holding AG }(6.0 \%) \\
\text { 2. Invesco Ltd. }(1.6 \%) \\
\text { 3. Banque Lombard Odier }(1.4 \%) \\
\text { 4. Close Brothers Group }(1.4 \%) \\
\text { 5. Azimut Investments }(0.5 \%)\end{array}$ & $\begin{array}{l}\text { 1. ING }(18.8 \%) \\
\text { 2. Standard Chartered }(9.6 \%) \\
\text { 3. Sumitomo Mitsui }(9.5 \%) \\
\text { 4. Bank of China }(8.4 \%) \\
\text { 5. Société Générale }(7.6 \%)\end{array}$ \\
\hline Mercuria & 121.0 & Energy & $\begin{array}{l}\text { Private } \\
\text { (Switzerland) }\end{array}$ & $\begin{array}{l}\text { 1. } 3 \text { company executives }(30.0 \%) \\
\text { 2. Employees }(20.2 \%) \\
\text { 3. Marco Dunand }(13.3 \%) \\
\text { 4. ChemChina }(12.0 \%) \\
\text { 5. Daniel Jaeggi }(11.8 \%)\end{array}$ & $\begin{array}{l}- \\
- \\
- \\
-\end{array}$ & $\begin{array}{l}\text { 1. Sumitomo Mitsui }(13.4 \%) \\
\text { 2. Mizuho Financial }(9.7 \%) \\
\text { 3. ING }(7.8 \%) \\
\text { 4. ICBC }(7.5 \%) \\
\text { 5. Société Générale }(7.0 \%)\end{array}$ \\
\hline Cargill & 113.5 & Agriculture & $\begin{array}{l}\text { Private } \\
\text { (US) }\end{array}$ & $\begin{array}{l}\text { 1. Cargill \& MacMillan family } \\
(90.0 \%) \\
\text { 2. Employee stock owners }(8.0 \%) \\
\text { 3. Senior managers }(2.0 \%) \\
\text { - }\end{array}$ & $\begin{array}{l}\text { 1. Charles Schwab Corp. }(2.5 \%) \\
\text { 2. Prudential Financial }(2.2 \%) \\
\text { 3. Wellington Management }(1.7 \%) \\
\text { 4. MetLife Investment }(1.6 \%) \\
\text { 5. BlackRock Inc. }(1.5 \%)\end{array}$ & $\begin{array}{l}\text { 1. BNP Paribas }(15.3 \%) \\
=2 . \text { JP Morgan Chase }(13.7 \%) \\
=2 . \text { Bank of America }(13.7 \%) \\
=2 . \text { Citi }(13.7 \%) \\
\text { 5. Deutsche Bank }(12.0 \%)\end{array}$ \\
\hline
\end{tabular}

Table 1: Major Commodity Traders’ Principal Asset Class, Ownership Structures and Linkages to Financial Markets (continued...) 


\begin{tabular}{|c|c|c|c|c|c|c|}
\hline & $\begin{array}{l}\text { Revenues } \\
2019 \\
\text { (US\$ bn) }\end{array}$ & $\begin{array}{l}\text { Principal } \\
\text { asset } \\
\text { class }\end{array}$ & $\begin{array}{l}\text { Ownership } \\
\text { structure } \\
\text { (location of } \\
\text { headquarters) }\end{array}$ & $\begin{array}{l}\text { Leading shareholders } \\
\text { (percentage of shares } \\
\text { outstanding, 2020) }\end{array}$ & $\begin{array}{l}\text { Leading bondholders } \\
\text { (percentage of outstanding } \\
\text { debt, 2020) }\end{array}$ & $\begin{array}{l}\text { Leading loan underwriters } \\
\text { (percentage of total proceeds, } \\
2018-20 \text { ) }\end{array}$ \\
\hline COFCO & 72.1 & Agriculture & $\begin{array}{l}\text { State-owned } \\
\text { (China) }\end{array}$ & $\begin{array}{l}\text { 1. People's Republic of China } \\
(100 \%) \\
- \\
- \\
-\end{array}$ & $\begin{array}{l}\text { 1. Dacheng Fund }(0.8 \%) \\
\text { 2. Banque Lombard Odier }(0.6 \%) \\
\text { 3. Great Wall Fund }(0.4 \%) \\
\text { 4. Schroder Investment }(0.4 \%) \\
\text { 5. Assicurazioni Generali }(0.3 \%)\end{array}$ & $\begin{array}{l}=1 . \text { ICBC }(4.0 \%) \\
=1 . \text { Westpac Banking Corp. }(4.0 \%) \\
=1 . \text { Oversea-Chinese Bank }(4.0 \%) \\
=1 . \text { China Development Bank }(4.0 \%) \\
=1 . \text { China Construction Bank }(4.0 \%)\end{array}$ \\
\hline $\mathrm{ADM}$ & 64.7 & Agriculture & $\begin{array}{l}\text { Public } \\
\text { (US) }\end{array}$ & $\begin{array}{l}\text { 1. Vanguard Group }(9.5 \%) \\
\text { 2. State Fam Mutual }(9.2 \%) \\
\text { 3. BlackRock Inc. }(6.7 \%) \\
\text { 4. State Street Corp }(6.2 \%) \\
\text { 5. Wellington Management }(4.1 \%)\end{array}$ & $\begin{array}{l}\text { 1. Prudential Financial }(3.6 \%) \\
\text { 2. BlackRock Inc. }(3.1 \%) \\
\text { 3. JPMorgan Chase }(2.2 \%) \\
\text { 4. Vanguard Group }(2.0 \%) \\
\text { 5. MetLife Investment }(1.7 \%)\end{array}$ & $\begin{array}{l}=1 . \text { Bank of America }(25.0 \%) \\
=1 . \text { JP Morgan }(25.0 \%) \\
=1 . \text { Citi }(25.0 \%) \\
=1 . \text { Barclays }(25.0 \%) \\
-\end{array}$ \\
\hline Wilmar & 42.6 & Agriculture & $\begin{array}{l}\text { Public } \\
\text { (Singapore) }\end{array}$ & $\begin{array}{l}\text { 1. ADM }(22.2 \%) \\
\text { 2. Kuok Brothers Sdn. Bhd. }(18.6 \%) \\
\text { 3. Kerry Group }(5.8 \%) \\
\text { 4. Longhlin Asia }(5.4 \%) \\
\text { 5. Harpole Resources }(4.1 \%)\end{array}$ & $\begin{array}{l}- \\
- \\
- \\
-\end{array}$ & $\begin{array}{l}\text { 1. DBS Group Holdings }(22.4 \%) \\
\text { 2. United Overseas Bank }(20.3 \%) \\
=3 . \text { Mizuho Financial }(11.4 \%) \\
=3 . \text { Mitsubishi UFJ }(11.4 \%) \\
=3 . \text { HSBC Holdings PLC }(11.4 \%)\end{array}$ \\
\hline Bunge & 41.1 & Agriculture & $\begin{array}{l}\text { Public } \\
\text { (US) }\end{array}$ & $\begin{array}{l}\text { 1. T Rowe Price Group }(11.2 \%) \\
\text { 2. Vanguard Group }(9.2 \%) \\
\text { 3. BlackRock Inc. }(6.5 \%) \\
\text { 4. UBS AG }(3.2 \%) \\
\text { 5. Continental Grain }(2.8 \%)\end{array}$ & $\begin{array}{l}\text { 1. Vanguard Group }(3.2 \%) \\
\text { 2. BlackRock Inc. }(3.2 \%) \\
\text { 3. Franklin Resources Inc. }(2.5 \%) \\
\text { 4. Dimensional Fund }(2.2 \%) \\
\text { 5. JPMorgan Chase }(2.2 \%)\end{array}$ & $\begin{array}{l}\text { 1. Sumitomo Mitsui }(14.5 \%) \\
=2 . \text { US Bancorp }(9.0 \%) \\
=2 . \text { Citi }(9.0 \%) \\
=2 . \text { BNP Paribas }(9.0 \%) \\
\text { 5. JPMorgan Chase }(7.7 \%)\end{array}$ \\
\hline $\begin{array}{l}\text { Louis } \\
\text { Dreyfus }\end{array}$ & 34.5 & Agriculture & $\begin{array}{l}\text { Private } \\
\text { (Netherlands) }\end{array}$ & $\begin{array}{l}\text { 1. Margarita Louis-Dreyfus }(\approx 55.0 \%) \\
\text { 2. Abu Dhabi Developmental } \\
\text { Holding Company }(45.0 \%) \\
\text { - }\end{array}$ & $\begin{array}{l}\text { 1. DNCA Finance }(2.8 \%) \\
\text { 2. Montagu Private Equity }(1.5 \%) \\
\text { 3. Close Brothers Group }(1.3 \%) \\
\text { 4. BlackRock Inc. }(1.2 \%) \\
\text { 5. La Francaise AM }(0.8 \%)\end{array}$ & $\begin{array}{l}\text { 1. ING }(10.9 \%) \\
\text { 2. Cooperatieve Rabobank }(8.9 \%) \\
\text { 3. Sumitomo Mitsui }(7.8 \%) \\
\text { 4. DBS Group Holdings }(7.3 \%) \\
\text { 5. Citi }(6.5 \%)\end{array}$ \\
\hline
\end{tabular}

\section{Table 1: Major Commodity Traders' Principal Asset Class, Ownership Structures and Linkages to Financial Markets}

Source: Bloomberg Professional (2020) and Thomson Reuters Eikon (2020)

Note: Mercuria equity ownership data current as of $20^{\text {th }}$ August 2018. All other data current as of $31^{\text {st }}$ December 2020. 
billionaire heir, Margarita Louis-Dreyfus, widow of the great grandson of the company's founder.

Before delving into the various metrics of financialization, it is worthwhile examining the overall profitability of the ten commodity trading firms to provide some context for our analysis. To this end, Figure 1 presents the differential profits of these companies. Conceived by Jonathan Nitzan and Shimshon Bichler (2009), this measure gauges the profitability of any one group of firms against a benchmarked 'average'. For the purposes of this research, differential profits are calculated by dividing the annual net income of the commodity traders by the corresponding annual average net income of firms in the Compustat 1000: the 1000 largest USheadquartered, non-financial companies in the Compustat database ranked by net income (for further details on the compilation of the Compustat 1000 dataset see Table A1). The bottom chart in Figure 1 presents the differential profits of the commodity traders as staggered averages because the net income data for each firm is not co-extensive for the period of interest. As such, the solid line in the bottom panel that starts from 1993 tracks the weighted average net income of Cargill and ADM relative to the Compustat 1000 as these are the only firms in this study with net income data available from 1993 through to 2019. In 1995, Vitol is then added, and this iterative process is continued so that the net income of all the trading firms is eventually incorporated into the analysis. The top chart presents the inflation-adjusted price levels and volatility of the Thomson Commodity Price Index.

As Figure 1 shows, there is a clear long-term trajectory which is discernible for the major commodity traders. Beginning from low levels at the turn of the twenty-first century, their differential profits rose to a peak in 2008 and declined thereafter. Moreover, this pattern broadly mirrors the commodity price dynamics in the same period: surging profits coincided 


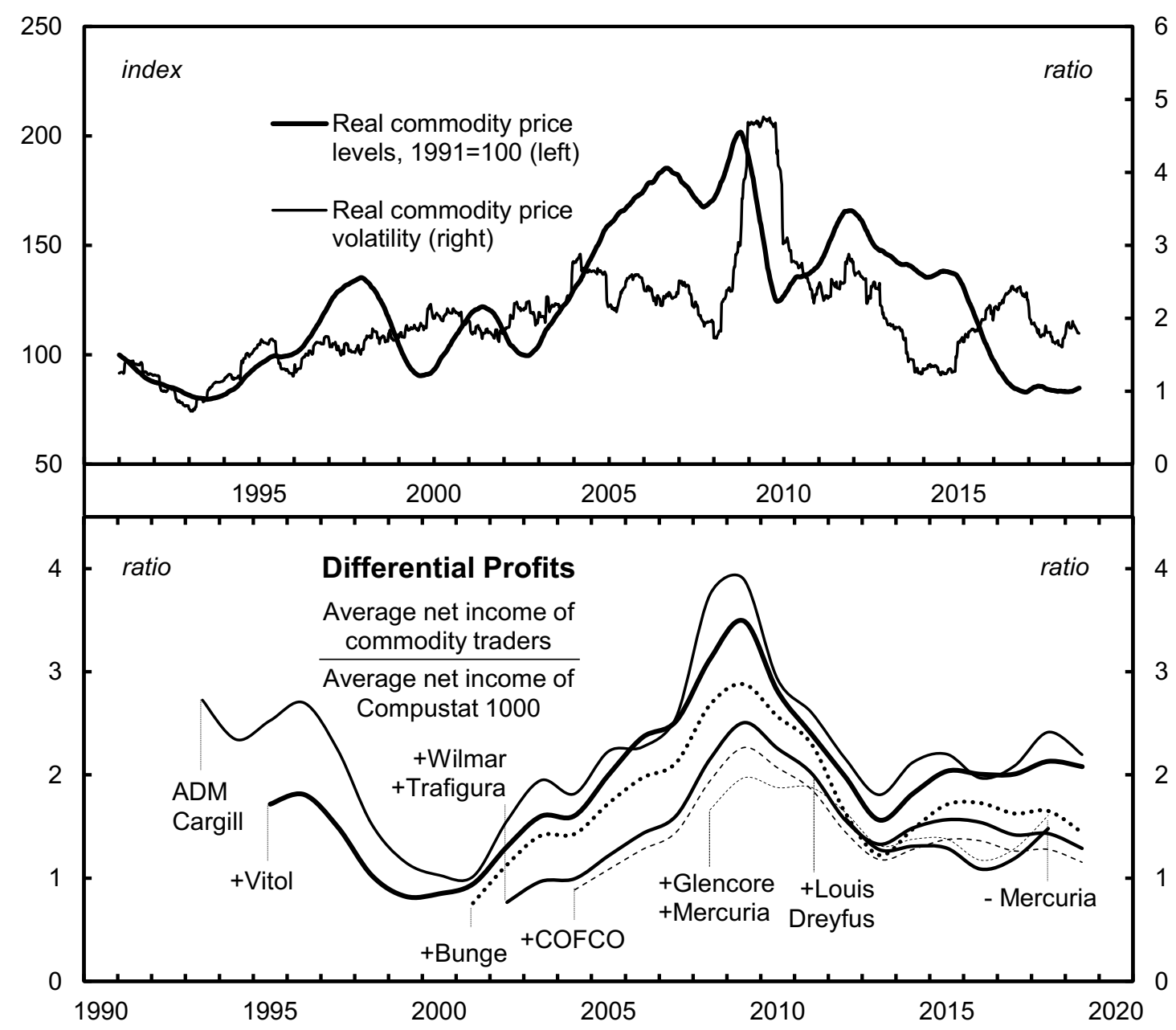

Figure 1. Commodity Trading Firms' Differential Profitability and Commodity Price

\section{Instability}

Source: Bloomberg Professional (2020), Compustat (2020), Global Financial Data (2020) and Thomson Reuters Eikon (2020)

Note: Commodity prices are represented by the Thomson Reuters Core Commodity CRB Index, and are inflation-adjusted by Global Financial Data. Commodity price volatility is the standard deviation of the weekly rate of change of commodity prices in an annual-moving window, and commodity price levels are presented as one-year moving averages. Series data are smoothed to 2-year moving averages. Series code for Compustat 1000: ni.

with elevated price levels and heightened volatility. The trading houses tend to thrive during periods of price instability in large part because of their unparalleled reach into global trade flows. As they are privy to myriad streams of commercially relevant information, commodity trading firms have a lead in the 'price discovery' process. And during periods of market turmoil, 
the price discovery lead tends to widen as the commodity traders take advantage of the disorientation of other entities. Growing informational asymmetries afford commodity traders the opportunity of navigating profit opportunities through arbitrage, speculation or the increased provision of risk-management services to less informed entities (Baines, 2017; Murphy et al., 2012; Staritz et al., 2018).

The view that commodity trading firms can benefit greatly from instability is widely accepted among insiders of the commodity trading business itself. To take one example (for others see e.g. Jenkins, 2018, p. 15; Kingsman, 2019, p. 147), in a report titled 'The Value in Volatility' produced by Deutsche Bank on the eve of Glencore's initial public offering in 2011 it was argued:

'The increasing frequency of extreme weather events and the likelihood of more political intervention (such as export bans) in commodities will further exacerbate the trend of increasing volatility in our view. As commodities gain popularity as an asset class, the financial aspect of demand, which is arguably more susceptible to changes in sentiment will also continue to amplify volatility in our view. Commodity price volatility may not suit the pure producers, and increased volatility could arguably lead to an equity de-rating. However ... Glencore's trading business actually benefits directly from the volatility and we believe the equity could out-perform in periods of volatility.' (Sporre et al. 2011, p. 6)

The bullish sentiment articulated in this passage, along with the soaring differential profits at the height of the commodity boom as recorded in Figure 1, serve as a stark reminder that the exhaustion of Cheap Nature and the ongoing financialization of accumulation that Jason Moore sees as prefigured in the last commodity boom will have highly uneven effects. Rather than simply spelling doom for capital in general, there are some corporations - the commodity 
trading firms foremost among them - which are well positioned to benefit from the turmoil. Indeed, the salience of extreme weather and geopolitical turbulence has only increased since the publication of Deutsche Bank's report. In view of the gathering storm, the remainder of the article proceeds in two steps. The next section examines the changes undergone by the major commodity trading firms with respect to the two key facets of corporate financialization emphasized in the literature: the financialization of accumulation and the rise of shareholder value norms. And the subsequent section investigates whether processes of financialization may actually create new opportunities via financial activism to push commodity trading firms to reverse the ecological and social harms of their operations.

\section{Mapping Financialization of the Commodity Trading Firms (I): Accumulation}

How does one assess the degree to which corporate accumulation has become financialized? Some researchers proceed by analysing shifts in company asset structures (e.g. Davis, 2018; Rabinovich, 2019). Using this scholarship as our lead, we examine the physical asset intensity of commodity traders to determine how tangible fixed assets as a percentage of total assets have changed through time. This can be seen as an inverse proxy for the financialization of firm-level accumulation: the lower the physical asset intensity, the higher the degree of financialization, and vice versa. A decline in physical assets as a percentage of total assets relates to financialization in that it reflects the substitution of financial investment for 'real' investment (Baud \& Durand, 2012; Krippner, 2012). This aspect of financialization is particularly relevant to our analysis as the existing literature maintains that the agricultural commodity traders are expanding their financial activities and becoming more like financial firms (Murphy et al., 2012, p. 5; Salerno, 2017, p. 215). 
The top panel of Figure 2 displays the data separately for each of the ten trading companies, while the bottom panel presents the data as staggered averages alongside the corresponding metric for the Compustat 1000. Data in the top panel indicate considerable diversity among the commodity trading firms (see Figure A2 for a more granular picture of the commodity trading firms' balance sheets). The privately-held traders - Mercuria, Trafigura and Vitol - are the most financialized in terms of their asset base, while the agricultural commodity traders have

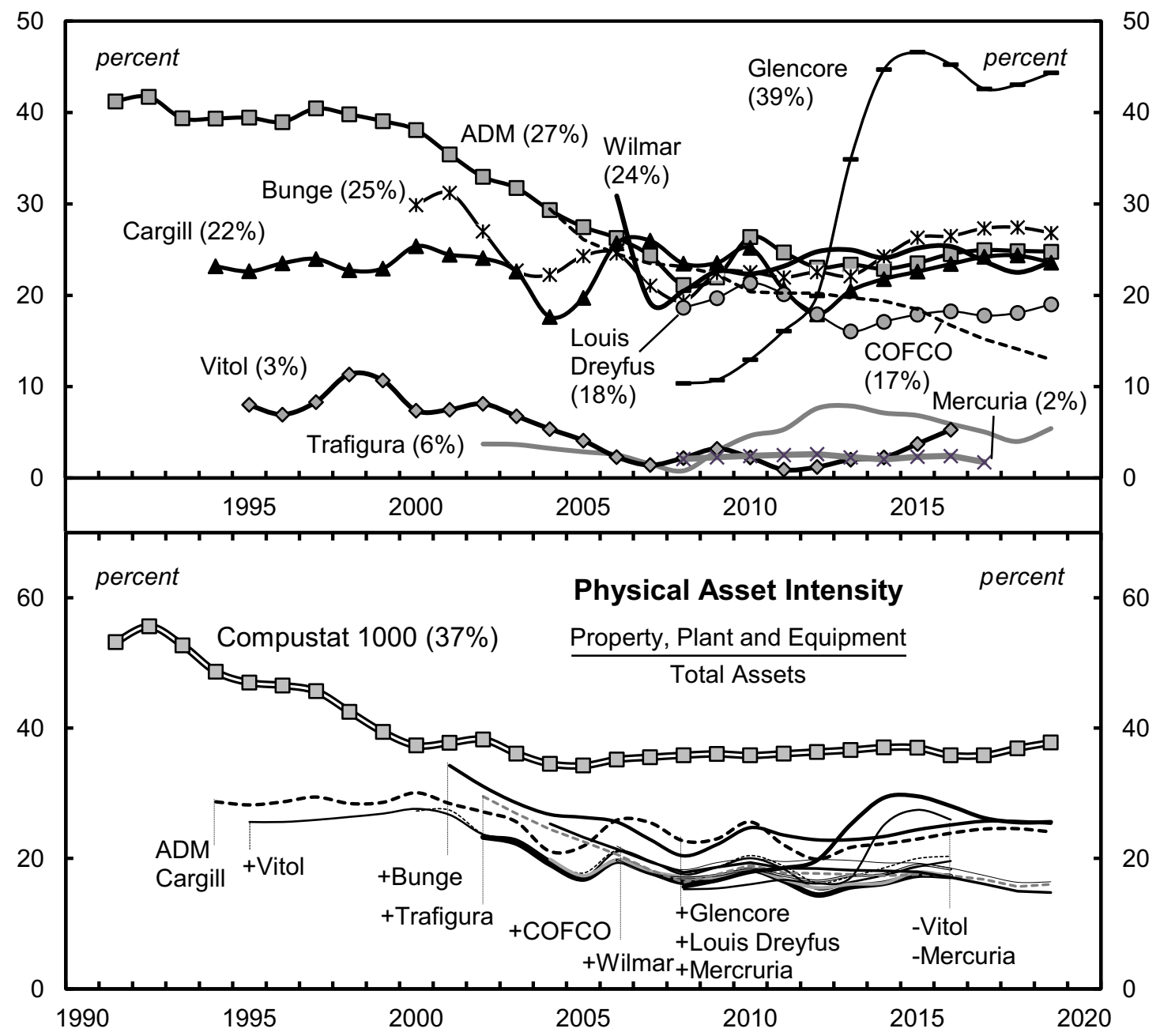

Figure 2. Commodity Trading Firms' Physical Asset Intensity

Source: Compustat (2020), Bloomberg Professional (2020) and Orbis (2020)

Note: Figures in parentheses are the average values for 2010-2019. Series data are smoothed to 2-year moving averages. Series codes for Compustat 1000: ppent and at. 
converged on asset-medium business models (see also Pirrong, 2014). The publicly-listed energy and minerals trading firm Glencore is unique. The sharp rise in its physical asset intensity is chiefly attributable to its US\$30 billion acquisition of mining giant Xstrata in 2013, the largest ever commodities transaction outside of the oil sector (Blas, 2013).

There are also other significant shifts in the commodity traders' asset structures, which are less clearly registered in Figure 2. Specifically, in response to falling trading margins brought by increasing price transparency and declining price volatility, the privately-held trading firms expanded in other parts of the energy and minerals supply chain between 2010 and 2014 in search for profits. Trafigura acquired key storage and distribution assets in Australia to become the country's largest independent fuel retailer, Vitol massively expanded its oil refining and petrol distribution network in Africa through a series of deals with Royal Dutch Shell, and Mercuria bought up the physical commodity trading operations of JPMorgan, including its large-scale metal warehousing facilities (Prosser, 2011; Trafigura, 2013; Zhdannikov and Antonioli, 2014). Tellingly, these shifts led the business consultancy Oliver Wyman to herald a new era characterized by 'the industrialization of commodity trading' - an altogether different narrative to that advanced in the financialization literature on the trading firms (Franke et al., 2015). To reinforce this point about incipient trends in industrialization in the commodity trading sector, it is worth examining the staggered averages in Figure 2. They indicate that physical asset intensity was generally declining during the onset of the commodity boom in the 2000s. However, by the 2010 s there was a flattening out in this trend, just as there has been with the Compustat 1000. This indicates that the financialization of the commodity trading firms' asset structures has levelled-off and in some cases been reversed. 
Beyond examining the changing asset structures of the commodity traders, how else might we go about measuring the extent to which these companies are engaging in financialized forms of accumulation? One possible route is to follow other studies of non-financial firms and determine the degree to which commodity traders generate income from their financial divisions as well as from interest payments and dividends (e.g. Davis, 2018; Rabinovich, 2019; Orhangazi, 2008). Metrics for the commodity traders' financial division income are presented in Figure 3, and metrics for their interest and dividend income are included in the Appendix (Figures A3 and A4). As we can see in Figure 3, only three commodity traders have reported financial division income - Cargill, $\mathrm{ADM}$ and $\mathrm{COFCO}$ - so we have to be circumspect in gleaning general insights from these data. Nonetheless, what we find is that Cargill's financial division appeared to peak in importance in 2001 - contributing a staggering $68 \%$ of the firm's net profits, but by 2013 the financial division's contribution to net profits fell to $14 \%$. The contribution of ADM's financial division to operating income peaked at 13\% in 2004 and remained at elevated levels until the peak of the commodity boom in 2008, after which it was never able to significantly recover. COFCO's financial division has also seen its share of company gross profits fall from $2.1 \%$ in 2013 to $0.5 \%$ in 2017 . As the bottom chart in Figure 3 shows, these developments resemble longer running trends in the de-financialization of profits among the Compustat 1000 (see also Rabinovich, 2019; Soener, 2020).

The declining contribution of the three commodity traders' financial divisions to overall profits is reflective of broader trends in commodity trading away from some financial activities in the context of diminished profitability in the mid-2010s (Terazono, 2015). In 2015, Bunge spanoff its private equity operations as part of a broader shutdown of its asset management activities (Singh and Rowling, 2015). And one year later, Cargill completed the closure of its private equity arm, Black River Asset Management, as it sought to renew its focus on its own core 
competencies. This shift in focus culminated in Cargill moving out of the fund management business altogether with the sale of it assess management company, CarVal Investors, in 2019 (Meyer, 2019). Similarly, in 2017 Louis Dreyfus closed down Edesia Asset Management,

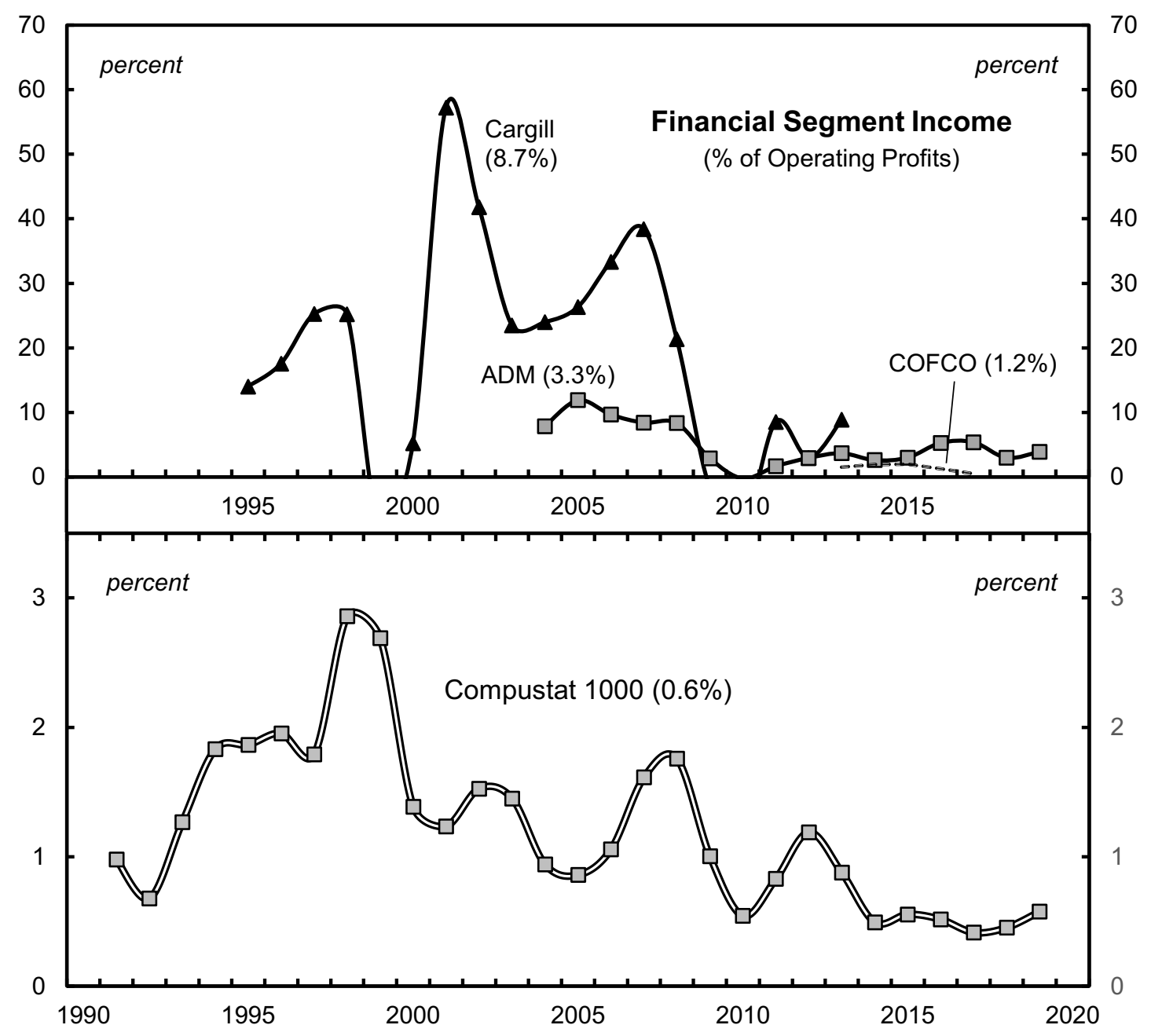

Figure 3. Commodity Trading Firms' Financial Divisions

Source: Bloomberg Professional (2020) and Compustat (2020)

Note: Cargill time-series is segment net income as a percentage of total net income and COFCO time-series is segment gross profits as a percentage of total gross profits as segment operating profit data for these two companies are unavailable. Figures in parentheses are the average values for 2010-2019. Series data are smoothed to 2-year moving averages. Operating profits for Compustat 1000 is defined simply as the sum of net income, interest expenses and tax payments. Series codes for Compustat 1000: ops, ni, xint and txc. 
which was at the time one of the largest commodity hedge funds in the world (Kingsman, 2018). Echoing the explanations offered by other major commodity trading firms that downsized their financial operations during this period, Louis Dreyfus stated that their decision to close Edesia Asset Management was ‘in line with the group's strategic decision to focus its resources on its core physical operations as a merchant and processor of agricultural goods' (cited by Reuters, 2017).

Overall, then, we find that the accumulation patterns of commodity trading firms are highly variegated, but that the general trend towards declining physical asset intensity abated in the 2010s. Furthermore, according to available data on financial income streams, the accumulation of the commodity trading firms was less financialized in the 2010 s than in the previous decade. The shift away from financial activities is further evidenced by the expanded physical footprint of the major energy and mineral trading firms in the first half of the 2010s, and the closure of many financial operations by the agricultural commodity traders in the second half of the 2010 s. That these shifts took place in the context of diminished profitability has key conceptual implications. While Moore argues that diminished profitability may lead to a shift towards more financial activities for capital in general; for the major commodity trading firms, at least, depressed profits in their trading operations have led to the reverse: a strategic reorientation away from financial activities and a renewed focus on their physical supply chains.

\section{Mapping Financialization of the Commodity Trading Firms (II): Shareholder Value}

In the previous section we explored the first facet of financialization emphasized in the literature - the rise of financial activities - and we found evidence that suggests that during the 2010s the major commodity trading firms have actually been de-financializing in this respect. 
But what about shareholder value norms? Have these norms suffused all the commodity traders so that more value is distributed to equity holders via dividends and stock buybacks? And what impact might such norms have on corporate practices of acquisition and divestiture before, during and after the commodity boom?

Figure 4 helps us begin to answer these questions by presenting the shareholder payout ratio (dividend payments and stock buybacks as a share of net income), a metric used to gauge the degree of shareholder value enhancement (e.g. Milberg, 2008, pp. 438-439). The top panel indicates that rising shareholder value norms are to varying degrees evident in commodity trading firms of all types - whether they be public, private or state-owned. Publicly-listed Bunge, ADM and Glencore and privately-held Vitol have distributed the most to equity-holders: respectively disbursing $76 \%, 73 \%, 72 \%$ and $71 \%$ of net income in dividends and stock buybacks from 2010-19. Meanwhile privately-held Cargill, state-owned COFCO, and publiclylisted Wilmar have distributed the least in the same period: $24 \%, 29 \%$ and $31 \%$ respectively. In the bottom panel with the staggered averages, we see that there have been two waves of shareholder payouts for the commodity traders, reaching a peak at the turn of the twentieth century, only to surge to new heights in the second half of the 2010s. Indeed, the shareholder payout ratio for all but one of the major commodity traders for which we have data peaked from 2015-19, and every staggered average reaches a climax during this period as well, indicating a clear upward trend that converges with the payout commitments of the Compustat 1000 as a whole. These data therefore lend strong support to the view that the commodity traders have become more financialized in terms of their shareholder value orientation.

According to the literature on corporate financialization, a likely corollary of this trend towards shareholder value enhancement is increased dependence on subcontracting as a means of 
minimizing costs and externalizing risk. Although comprehensive data on subcontracting activities are elusive, there is considerable evidence that subcontracting does play a significant role in the business models of commodity trading firms, often in ways that are injurious to human rights and harmful to the environment. For example, it has been revealed that Glencore outsources mining operations to cooperatives that employ child labour in conditions where fatal accidents are commonplace (Kollbrunner, 2020). Similarly, agricultural trading firms such as

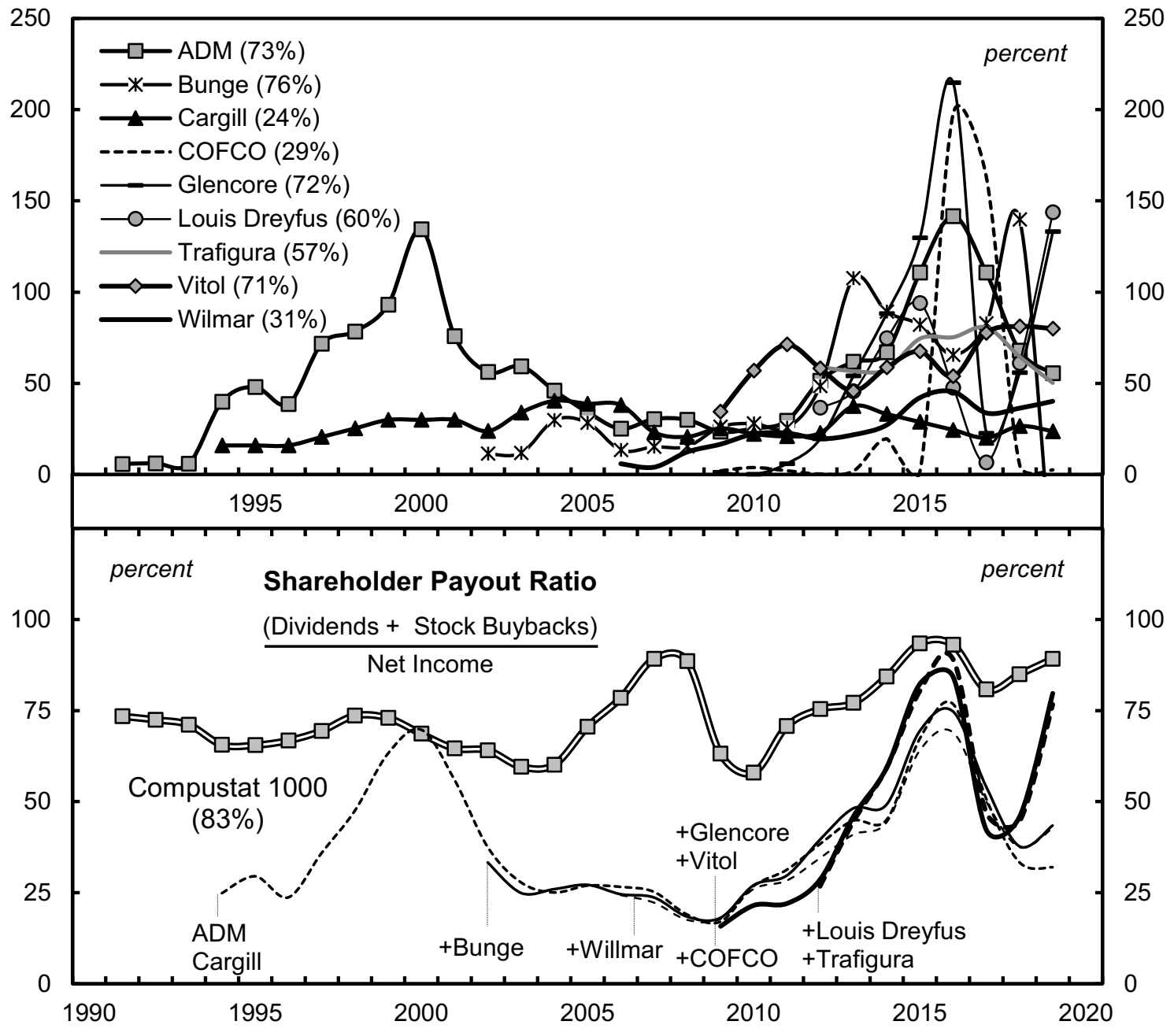

Figure 4. Commodity Trading Firms' Shareholder Payouts

Source: Bloomberg Professional (2020) and Compustat (2020)

Note: Figures in parentheses are the average values for 2010-2019. Series data are smoothed to 2-year moving averages. Series codes for Compustat 1000: dvt, prstkc and ni. 
Wilmar have been found to source significant quantities of palm oil from 'shadow companies,' which are not subject to its social and environmental commitments (Chain Reaction Research, 2018). And in South America, an apparent strategic ignorance about the provenance of the oilseeds and grains that they process has long been exhibited by major agricultural traders to distance themselves from responsibility for deforestation and human rights abuses. Although such knowledge limitations could be overcome through more robust tracing practices, this would be costly and thereby militate against shareholder value priorities (Freidberg, 2017).

Table 2 teases out some of the implications of shareholder value advancement for company acquisitions policy by presenting the number of firms in which the ten commodity traders acquired $50 \%$ or more of equity in five-year periods from 1990 to 2019 . Table 3 looks at corresponding patterns of company divestiture policy, presenting the number of subsidiaries

\begin{tabular}{lrrrrrrr}
\hline & $1990-94$ & $1995-99$ & $2000-04$ & $2005-09$ & $2010-14$ & $2015-19$ & Total \\
\hline ADM & 3 & 9 & 8 & 10 & 7 & 13 & 50 \\
Bunge & 0 & 4 & 8 & 12 & 10 & 4 & 38 \\
Cargill & 16 & 20 & 19 & 14 & 28 & 16 & 113 \\
COFCO & 1 & 1 & 1 & 5 & 10 & 6 & 24 \\
Glencore & 0 & 8 & 10 & 8 & 21 & 3 & 50 \\
Louis Dreyfus & 8 & 6 & 6 & 8 & 11 & 0 & 39 \\
Mercuria & - & - & 0 & 3 & 5 & 4 & 12 \\
Trafigura & 0 & 0 & 1 & 0 & 5 & 2 & 8 \\
Vitol & 2 & 2 & 0 & 4 & 3 & 3 & 14 \\
Wilmar & 0 & 6 & 1 & 15 & 7 & 3 & 32 \\
\hline Total & 30 & 56 & 54 & 79 & 107 & 54 & \\
\hline
\end{tabular}

Table 2. The Number of Acquisitions of Commodity Trading Firms, 1990-2019

Source: Thomson Reuters SDC (2020)

Note: Only companies in which the commodity trading firm has bought at least $50 \%$ of equity are included. 
for which the ten commodity traders sold $50 \%$ or more of equity during the same period. ${ }^{2}$ As suggested above, research on the financialization of mining firms shows that shareholder pressures accentuated pro-cyclical dynamics of increased acquisitions in the upsurge of commodity booms, and increased divestitures during subsequent downswings. Table 2 indicates pro-cyclical dynamics with acquisitions peaking either in 2005-09 or 2010-14, when commodity prices were at elevated levels, for nine of the ten major commodity traders. Moreover, Table 3 suggests that, at least at an aggregate level, divestitures reached their highest levels when commodity prices were depressed: from 1995-1999 and 2015-19. Interestingly, these figures conform with our findings in the previous sub-section: with energy and mineral commodity traders acquiring large-scale industrial assets in 2010-14; and agricultural commodity traders divesting financial subsidiaries in 2015-19.

\begin{tabular}{lrrrrrrr}
\hline & $1990-94$ & $1995-99$ & $2000-04$ & $2005-09$ & $2010-14$ & $2015-19$ & Total \\
\hline ADM & 0 & 1 & 0 & 3 & 1 & 1 & 6 \\
Bunge & 1 & 5 & 3 & 0 & 4 & 0 & 13 \\
Cargill & 4 & 7 & 9 & 6 & 7 & 12 & 45 \\
COFCO & 0 & 0 & 0 & 0 & 2 & 2 & 4 \\
Glencore & 0 & 1 & 0 & 3 & 1 & 4 & 9 \\
Louis Dreyfus & 0 & 2 & 1 & 2 & 1 & 1 & 7 \\
Mercuria & - & - & 0 & 0 & 1 & 0 & 1 \\
Trafigura & 0 & 0 & 1 & 0 & 1 & 0 & 2 \\
Vitol & 0 & 3 & 0 & 0 & 0 & 0 & 3 \\
Wilmar & 0 & 2 & 0 & 3 & 1 & 0 & 6 \\
\hline Total & 5 & 21 & 14 & 17 & 19 & 20 & \\
\hline
\end{tabular}

Table 3. The Number of Divestitures of Commodity Trading Firms, 1990-2019

Source: Thomson Reuters SDC (2020)

Note: Only subsidiaries from which the commodity trading firm has sold at least $50 \%$ of equity are included.

The major agricultural commodity traders have engaged in the vast majority of divestitures with Cargill alone accounting for no less than $47 \%$ of sell-offs among the ten major commodity 
traders between 1990 and 2019. The processes of rationalization not only led to the closure of significant financial operations, they also involved significant layoffs and wage retrenchment in supply chains, especially in the aftermath of the commodity boom. This has contributed to heightened antagonisms between trading firms and dockyard and meatpacking workers in North America (Brenner \& Weissman, 2014; Heyman, 2015; Kurtz, 2018), as well as nationwide strike actions by port employees and workers operating in the agricultural commodity traders' grain and oilseed supply chains in Argentina (Tomas, 2018; 2019). Despite the complex transformations of the commodity trading firms, many of the insights regarding financialization and labour relations offered in the literature on the mining and oil industries thus appear to apply to the commodity traders themselves.

Taken together, our mapping of the commodity trading firms indicates that they are diverse, and that the financialization of these companies is highly variegated. Furthermore, when taken as a whole, we have shown the two most widely used registers to discern corporate financialization - the rise of accumulation via financial activities, and the ascendency of shareholder value norms - are disconsonant. While some trading firms are becoming less financialized in terms of the source of their profits, they are becoming more financialized in terms of the destination of profits, with dividend and share repurchase commitments reaching new heights after 2015. What is the significance of these findings? Will the commodity trading firms' intensified commitment to shareholder value mean that they will continue to prioritize short-term returns over long-term environmental and social concerns? Or can the commodity traders' linkages to capital markets be leveraged by groups aiming to reverse the environmental and social harms of these companies? The remainder of the article addresses these questions. 


\section{Regulating the Commodity Traders: Strategies in the Context of Financialization}

The existing literature has documented how, in the realm of public governance, commodity traders have successfully pushed back against regulatory initiatives to curb potentially destabilizing derivatives trading in the wake of the global financial crisis and commodity price spikes between 2007 and 2011 (Baines, 2017; Helleiner, 2018; Pagliari, 2018). However, few scholars have examined the limitations and possibilities of private governance with regard to the commodity trading firms (Schleifer \& Sun, 2018). In this respect, financial activism has emerged as one promising strategy for pushing these firms to commit to private governance programmes aimed at curtailing ecologically and socially destructive business practices (MacLeod \& Park, 2011). There are two main forms that financial activism can take. Through the use of 'voice', shareholders can put forth resolutions and vote at company annual meetings. Through the use of 'exit', shareholders and creditors can shape company policy by threatening to divest and discontinue credit. Exploring the limits and possibilities of these strategies allows us to better grasp potential paradoxes of financialization. While some facets of financialization may fuel the destructive behaviour of commodity trading firms, it may also open up ways for shareholders and creditors to pressure companies to reign in that destructive behaviour.

\section{Shareholder Resolutions}

We begin by considering shareholder resolutions, which investors can put forward at annual meetings to steer company policies. Perhaps stating the obvious, shareholder resolutions are unlikely to have much of an impact on the behaviour of most commodity trading firms simply because of their ownership structures. Table 1 revealed that in terms of equity holdings, the preponderance of private and state ownership, founding families, senior employees and managers, as well as individuals and entities closely connected to commodity trading shields most of these companies from the pressures of activist shareholders. 
Of the ten major commodity trading firms, only two - ADM and Bunge - are owned in any significant way by outside shareholders with no clear connection to commodity trading. Here we see that the equity of ADM and Bunge is dominated by giant asset managers, including the 'big three' of BlackRock, State Street and Vanguard (see also Clapp, 2019). The big three have gained a reputation as 'passive investors' merely following an index (Fichtner et al., 2017), but in recent years have pledged to use resolutions and voting against management to register their dissatisfaction with businesses that fail to improve environmental and social governance (Kerber, 2016; Flood, 2017). Critics have dismissed these pronouncements as hollow and argue that, in the case of BlackRock, increasing 'green' rhetoric has actually coincided with decreasing support for environmental resolutions (Mooney, 2020).

According to data we compiled from Proxy Insight (2020), between 2010 and 2019, there was only one shareholder resolution put to vote at ADM and one at Bunge aiming towards ESG improvements, out of a total of 148 shareholder votes and 80 shareholder votes at these two companies, respectively. The shareholder resolution at ADM was put forward in 2011, and proposed the establishment of a target date for sourcing $100 \%$ certified sustainable palm oil, new plans for verifying supplier compliance, and a moratorium on palm oil expansion in peatlands and rainforests (Ceres, 2020). The resolution attracted only $4.2 \%$ votes in its favour, with BlackRock's funds voting against the resolution, State Street abstaining, and Vanguard not voting at all (Proxy Insight, 2020). Similarly, the shareholder resolution that was submitted to Bunge's annual meeting in 2015 proposed a time-bound plan to eliminate the contribution of its supply chain to expansion in peatlands, the clearing of 'high conservation value' or 'high carbon stock' forests, and human rights abuses. The resolution gained 29.3\% votes in its favour, but tellingly all the funds of the three major asset management companies voted against the resolution (Ceres, 2020; Proxy Insight, 2020). 
The reluctance of the three major asset management firms to pursue significant progress in environmental and social governance in the wider commodity sector is further reflected in our own research which shows that they voted in favour of only $10.7 \%$ of shareholder resolutions aiming for ESG-improvements in commodity firms between 2014 and 2019. In contrast, they voted in favour of no less than $95.9 \%$ of management resolutions seeking approval for dividend payments and stock buybacks (see Table A2). These data indicate that the asset management firms are more likely to use their influence to validate continued shareholder returns rather than mobilize behind strategies for ESG improvements which might diminish such returns. To the extent that the pursuit of short-term returns leads to socially injurious and ecologically damaging practices brought by outsourcing, cost-cutting and other activities, the major asset companies' continual embrace of shareholder value may - in spite of their rhetoric of sustainability - reinforce the trading firms' destructive tendencies.

At the same time, the failed passage of the shareholder resolutions at ADM and Bunge has been mitigated by successful shareholder engagement with these two companies through other ESG resolutions, which were withdrawn after securing commitments from management. For ADM, this entailed obtaining agreements from management between 2014 and 2019 to impose sustainability reporting requirements on suppliers, and for the company to produce reports on deforestation impacts and renewable energy goals. Similarly, for Bunge, the engagement led to management committing to reports on environmental impacts (Ceres, 2020). Importantly, it was not the big asset managers that drew up these resolutions that eventually elicited manager commitments, but state pension funds, ESG-centred mutual fund networks and organizations representing church-based endowments. It is also worth noting that the commitments secured from both ADM and Bunge are rather limited in scope: reporting and disclosure tend to be emphasized over pledges to curb deforestation; and where concrete commitments to limit 
deforestation exist, they tend to come without an explicit timeframe, and they tend to focus on illegal deforestation only (Drost et al., 2017; Steinweg et al., 2018). Without significant support from the major equity owners of ADM and Bunge, not least the three big asset management companies, the potential for more wide-ranging shareholder initiatives to improve ESG appears limited.

\section{Divestment Campaigns}

What about divestment as an alternative strategy of financial activism to curb the destructive behaviour of commodity trading firms? While the majority of divestment campaigns have been directed toward tobacco, weapons, and fossil fuel companies, activists are now setting their sights on the commodity trading firms, calling on shareholders, creditors and underwriters to use the traders' dependence on equity and debt markets to drive ESG improvements (Greenpeace, 2017). But the efficacy of equity divestment is limited for the same reasons as shareholder resolutions: there are not many trading firms which rely significantly on financing from shareholders external to the commodity trade. Furthermore, despite the ecological devastation in which the commodity trading firms are involved, major asset companies appear unwilling to engage in bold divestment initiatives. For example, BlackRock announced a widely vaunted new climate plan in January 2020, which entails reducing exposure to coal mining companies. But BlackRock has no intention of divesting from Glencore, despite the fact that it extracts more coal than coal mining giants BHP Billiton and Anglo American combined (Biesheuvel, 2020). ${ }^{3}$

There are also challenges to bringing about ESG improvements via credit divestment strategies. As Table 1 shows, bond ownership is widely dispersed, and this is likely to create collective action problems for bondholders that may want to influence the behaviour of commodity 
traders. We also see in Table 1 that the distribution of loan underwriting is more concentrated. Underwriting may therefore offer opportunities for activists to demand that banks withhold these services to commodity traders that show no signs of improving their environmental and social governance. Yet even this facet of divestment is limited by the fact that many of the commodity traders have been deleveraging in recent years as shown in Figure 5 - with the staggered average leverage ratio falling below that of the Compustat 1000. According to the sustainability risk think tank, Chain Reaction Research, such debt reduction limits the financing risks that commodity trading firms experience from divestment threats (Drost et al., 2019, p. 15). Moreover, these threats might be further blunted by shadow banking activities among commodity traders, such as receivables securitization in which companies take assets off their balance sheets and sell them as securities so as to raise funds (see Table A3). As these shadow banking activities obviate standard practices of company disclosure, they make it even more difficult for activist investors to trace the commodity traders' manifold sources of financing.

Given these considerations, we remain sceptical about the potential of financial activism to pressure commodity trading firms into adopting forms of private governance that would reverse the socially and ecologically harmful effects of their activities. Shareholder resolutions focusing on ESG improvements which gain majority votes are often rather unambitious and limited to improving reporting and disclosure requirements. And even when shareholder resolutions do lead to positive engagement from corporations, such responses may forestall more fundamental challenges to environmentally and socially damaging business practices (Neville et al., 2019, p. 126). Similarly, divestment campaigns may pose reputational risks to commodity trading firms, but these risks are attenuated by the myriad financing options open to these companies. As long as direct or indirect involvement in destructive practices - from coal mining to deforestation - remains profitable for commodity trading firms, securing 
financing will likely be assured unless stringent public regulations on company financing and supply chain management are in place (Campos \& Locatelli, 2020; Neville, 2020).

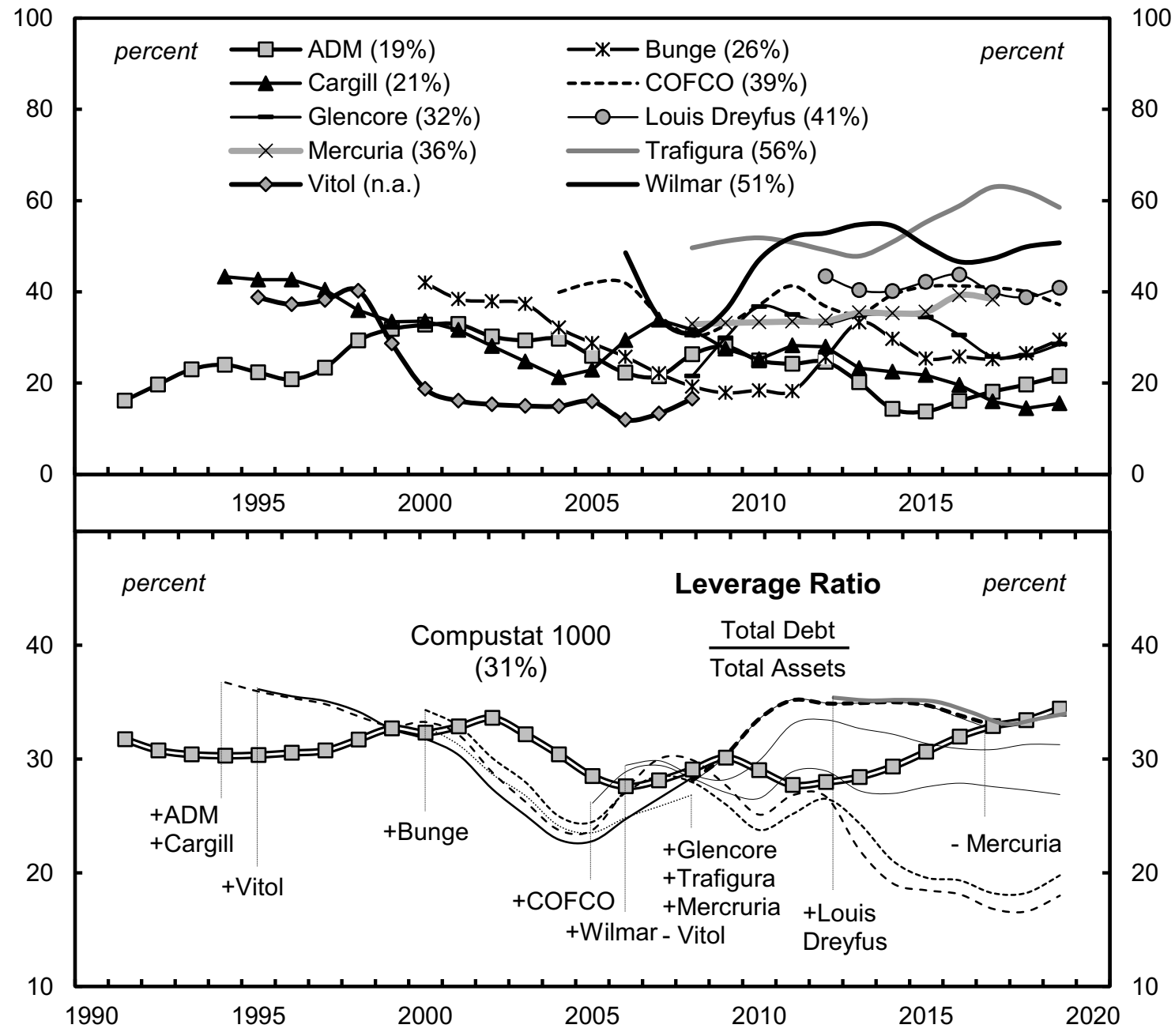

Figure 5. Commodity Trading Firms' Leverage

Source: Bloomberg Professional (2020), Compustat (2020) and Orbis (2020)

Note: Figures in parentheses are the average values for 2010-2019. Series data are smoothed to 2-year moving averages. Series codes for Compustat 1000: dlc, dltt and at.

\section{Conclusion}

The commodity trading firms play a pivotal role within global supply chains. While supporters credit them for balancing out dislocations in supply and demand in international commodity 
markets, critics point to the ecological and social harms in which commodity traders are implicated. As such, it is important that these firms are effectively conceptualized and empirically investigated. The small body of existing scholarship on the major commodity trading firms has used the concept of financialization to make sense of their transformations. Through engaging with this literature, and through mapping the changes undergone by the commodity trading firms, the article offers several key insights.

Firstly, we have demonstrated that the changes undergone by commodity trading firms are more complex and nuanced than is sometimes implied in existing analysis of corporate financialization. Like other verbal nouns ending in the suffix 'ization' - such as modernization or globalization - the concept of financialization is suggestive of change along discernible patterns from one condition to another (Steger, 2005, p. 13). But as we have indicated, the trading firms are diverse entities, and on an individual level their transformations do not straightforwardly accord with linear conceptions of change implicit in some scholarship on corporate financialization (see Christophers, 2015). Furthermore, when taken as a whole, we have shown that the two most widely used registers to discern corporate financialization - the rise of accumulation via financial activities, and the ascendency of shareholder value norms are incongruent. While commodity trading firms have exhibited an intensifying shareholder orientation through time, the accumulation strategies of many of the trading firms have become less financialized. These findings complicate the view commonly held in the literature on corporate financialization that the maximization of shareholder value and the financialization of accumulation run in parallel.

In some respects, the discordance between financial accumulation and shareholder payouts is reflected in the transformations of major non-financial corporations in general. The attentive 
reader will note that the major non-financial corporations - proxied by the Compustat $1000-$ peaked in terms of financial accumulation in the late 1990s (see also Rabinovich, 2019; Soener, 2020). They then became less financialized along this register in the 2000s and 2010s, and became more financialized in terms of shareholder payouts. The apparent incongruence between the two key parameters for financialization should perhaps be unsurprising. One feature of shareholder value norms is an emphasis on firms streamlining their operations and refocusing on their core competencies (Milberg, 2008), and this sometimes may entail downsizing financial activities. Such a refocusing on core operations certainly seems to have occurred among the commodity trading firms in the 2010s. Furthermore, the fact that this reorientation took place in the context of diminished profitability is telling. Moore, in line with many other critical scholars of financialization, argues that diminished profitability may lead to a shift towards more financial activities for capital in general. But for the major commodity trading firms, at least, depressed profits have led to the reverse: a strategic reorientation away from financial activities and a renewed focus on their physical supply chains.

It is beyond the scope of this article to establish whether such a strategic shift away from ancillary financial activities to core operations has taken place in other sectors. But the broader implication of our analysis is that the financialization of non-financial corporations should never be presupposed, and must instead be carefully parsed and empirically investigated. To succumb to the reflex of simply ascribing ever-more 'financialization' to particular corporations or 'financialization' in particular sectors without carefully articulating its parameters risks devaluing the conceptual currency of financialization itself(Mader et al., 2020, p. 3). As our findings on acquisitions and divestitures indicate, existing research on financialization in the commodity sector offers important pointers in navigating the complex terrain of commodity trading, not least in the emphasis it gives to the ways in which commodity 
price cycles intersect with shareholder priorities. But more work needs to be done to further advance our understanding of the variegated dynamics of financialization in the commodity sector and beyond.

Finally, we have found that in the context of variegated corporate financialization, there are several sources of commodity trader resilience in the face of financial activist pressures to reduce their harmful social and ecological impacts. The predominance of private ownership among the major commodity trading firms shields many of them from equity divestment campaigns. The threat of debt divestment is attenuated by the general dispersion of holdings in the commodity traders' bonds, as well as the deleveraging and increased use of shadow banking by several major trading firms in recent years. Given the weakness of divestment threats, the commodity trading firms may not feel significant pressure to curb ecological destruction and human rights abuses in their supply chains. Furthermore, we have found little evidence from shareholder voting data that the major asset management companies are pushing commodity traders to improve environmental and social governance. Shareholder resolutions aimed at ESG improvements among the commodity trading firms are few and far between. And the voting patterns of the major asset management firms in commodity sector resolutions indicate that they continue to value increasing dividend payouts and stock buybacks more than combatting ecologically and socially harmful activities within commodity supply chains.

Our intention is not to dismiss the efforts of activist investors to address problems relating to the commodity trading firms. Attempts at mobilizing pressures within financial channels should and must expand. But we submit that these efforts ought to be complemented with other forms of mobilization that extend beyond financial activism to encompass direct support for indigenous protest movements, pipeline blockades, consumer advocacy campaigns, electoral 
coalition-building, labour organizing, and all manner of other activities. Just as the commodity trading firms are protean and inexhaustibly dynamic in their business practices, so too must our efforts to check their power be multifaceted and relentless. The future of the planet may depend on it.

\section{Notes}

1. One exception is a working paper by Peter Gibbon (2014), which maps various financialization metrics for commodity trading firms. Gibbon's investigation uses brief snapshots and does not examine shareholder value maximization. Our work builds on Gibbon's efforts by expanding the temporal scope of analysis and exploring additional facets of financialization.

2. Ideally, we would present the value of these deals, but as the amounts exchanged in many of these transactions are not publicly disclosed, we offer a simple count of them instead.

3. BlackRock has pledged to divest from its portfolios all companies that derive more than $25 \%$ of their revenues from thermal coal. Glencore is the largest shipper of coal in the world, but falls well below BlackRock's threshold as thermal coal accounts for less than $10 \%$ of the diversified trading giant's total revenues (Biesheuvel, 2020).

\section{Acknowledgements}

Earlier versions of this article were presented at the Research in Progress Seminar Series at the University of Sussex, 8 November 2017, the International Political Economy Group Annual Conference, King's College London, 2-3 May 2019, and the Fourth Annual Conference of the Finance and Society Network, City, University of London, 12-13 December 2019. We wish to 
thank the participants at these events, the referees of this manuscript and the journal editorial board for their very insightful feedback. Moreover, we are grateful to Joel Roberts, D.T. Cochrane and James Wood for their helpful comments on previous versions of this manuscript. Finally, special thanks are due to Peter Gibbon for his invaluable guidance at the project's inception as well as Xuying Jiang for her assistance in processing the data. Any errors or shortcomings in the article are ours alone.

\section{References}

Ammann, D. (2009). The king of oil: The secret lives of Marc Rich. St. Martin's Press.

Amazon Watch. (2019). Complicity in destruction II: How northern consumers and financiers enable Bolsonaro's assault on the Brazilian Amazon. Amazon Watch. https://amazonwatch.org/assets/files/2019-complicity-in-destruction-2.pdf

Amnesty International. (2016). Côte d'Ivoire: Trafigura unrepentant 10 years after toxic waste dump. https:/www.amnesty.org/en/latest/news/2016/08/trafigura-unrepentant-10-yearsafter-toxic-waste-dump/

Arrighi, G. (1994). The long twentieth century: Money, power, and the origins of our times. Verso Books.

Baines, J. (2017). Accumulating through food crisis? Farmers, commodity traders and the distributional politics of financialization. Review of International Political Economy, 24(3), 497-537.

Baud, C., \& Durand, C. (2012). Financialization, globalization and the making of profits by leading retailers. Socio-Economic Review, 10(2), 241-266.

Berne Declaration. (Eds.) (2012). Commodities: Switzerland's most dangerous business. https://www.publiceye.ch/fileadmin/doc/Rohstoffe/2012_PublicEye_Commodities_EN_B ook.pdf

Biesheuvel, T. (2020, January 14). Big coal escapes BlackRock's new climate plan. Bloomberg. https://www.bloomberg.com/news/articles/2020-01-14/blackrock-s-tough-on-coal-planskirts-around-the-biggest-miners

Blas, J. (2013, May 3). Glencore Xstrata debuts with vow to cut costs and raise returns. Financial Times. https://www.ft.com/content/9f7e67a2-b3d6-11e2-b5a5-00144feabdc0 
Braunschweig, T., Kohli, A. \& Lang, S. (2019). Agricultural commodity traders in Switzerland: Benefitting from misery? Public Eye Report https://www.publiceye.ch/fileadmin/doc/Agrarrohstoffe/2019_PublicEye_AgriculturalCommodity-Traders-in-Switzerland_Report.pdf

Brenner, R., \& Weissman, S. (2014). Unions that used to strike. Jacobin Magazine. https://www.jacobinmag.com/2014/08/unions-that-used-to-strike/

Bloomberg Professional, (2020). Bloomberg Professional. https://www.bloomberg.com/prof essional/

Bowman, A. (2018). Financialization and the extractive industries: The case of South African platinum mining. Competition \& Change, 22(4), 388-412.

Campos, A. \& Locatelli, P. (2020, September 9). BlackRock silent on livestock in latest global warming policy. Mongabay. https://news.mongabay.com/2020/09/blackrock-silent-onlivestock-in-latest-global-warming-policy/

Ceres (2020). Shareholder resolutions database. https://www.ceres.org/ resources/tools/climate-and-sustainability-shareholder-resolutions-database

Chain Reaction Research. (2018). The chain: Wilmar and GAMA Group's zero-deforestation policies threatened by shadow companies. https://chainreactionresearch.com/the-chainwilmar-and-gama-group-zero-deforestation-policy-threatened-by-shadow-companies/

Chalmin, P. (1987). Traders and merchants: Panorama of international commodity trading, (E.E. Long-Michalke, Trans.; 2 ed.). Harwood Academic Publishers. (Original work published 1985)

Christophers, B. (2015). The limits to financialization. Dialogues in Human Geography, 5(2), 183-200.

Clapp, J. (2015). ABCD and beyond: From grain merchants to agricultural value chain managers. Canadian Food Studies, 2(2), 126-135.

Clapp, J. (2019). The rise of financial investment and common ownership in global agrifood firms. Review of International Political Economy, 26(4), 604-629.

Clapp, J., \& Helleiner, E. (2012a). International political economy and the environment: Back to the basics? International Affairs, 88(3), 485-501.

Clapp, J., \& Helleiner, E. (2012b). Troubled futures? The global food crisis and the politics of agricultural derivatives regulation. Review of International Political Economy, 19(2), 181207.

Clapp, J., \& Isakson, S.R. (2018). Risky returns: The implications of financialization in the food system. Development and Change, 49(2), 437-460.

Compustat (2020). Wharton Research Data Services. https://wrdswww.wharton.upenn.edu/pages/support/manuals-and-overviews/compustat/ 
Davis, G.F., \& Kim, S. (2015). Financialization of the Economy. Annual Review of Sociology, 41, 203-221.

Davis, L.E. (2018). Financialization and the non-financial corporation: An investigation of firm-level investment behavior in the United States. Metroeconomica, 69(1), 270-307.

De Los Reyes, J.A. (2017). Mining shareholder value: Institutional shareholders, transnational corporations and the geography of gold mining. Geoforum, 84, 251-264.

Dobler, G., \& Kesselring, R. (2019). Swiss extractivism: Switzerland's role in Zambia's copper sector. Journal of Modern African Studies, 57(2), 223-245.

Drost, S., De Wilde, J. \& Drennen, Z. (2017). Bunge: Key position in Cerrado state puts zero deforestation commitment at risk. Chain Reaction Research. https://chainreactionresearch.com/report/bunge-key-position-in-cerrado-state-puts-zerodeforestation-commitment-at-risk/

Drost, S., Mishra, K. \& Pietrowski, M. (2019). Cargill's new policies insufficient to fully mitigate deforestation risks in Brazil. Chain Reaction Research. https://chainreactionresearch.com/report/cargills-new-policies-insufficient-to-fullymitigate-deforestation-risks-in-brazil/

Elsby, A. (2020). Creaming off commodity profits: Europe's re-export boom and Africa's earnings crisis in the coffee and cocoa sectors. Review of African Political Economy, Online First, 1-13.

Epstein, G.A. (Ed.). (2005). Financialization and the world economy. Edward Elgar Publishing.

Fichtner, J., Heemskerk, E. M., \& Garcia-Bernardo, J. (2017). Hidden power of the Big Three? Passive index funds, re-concentration of corporate ownership, and new financial risk. Business and Politics, 19(2), 298-326.

Flood, C. (2017 August 31). Vanguard defies companies to back climate change resolutions. Financial Times. https://www.ft.com/content/717e8f1a-8db3-11e7-a352-e46f43c5825d

Forbes. (2016). Profile: Cargill-MacMillan family. https://www.forbes.com/profile/cargillmacmillan-1/\#5d6bb36e23b6

Franke, A., Lins, C., Perkins, A., Rechsteiner, R. \& Sharp, G. (2015). The industrialization of commodity trading. Oliver Wyman Insights. https://www.oliverwyman.com/content/dam/ oliver-wyman/global/en/2015/oct/Industry_Commodity\%20Trading-online-102315.pdf

Freidberg, S. (2017). Trading in the secretive commodity. Economy and Society, 46(3/4), 499521.

Froud, J., Johal, S., Leaver, A., \& Williams, K. (2006). Financialization and strategy: Narrative and numbers. Routledge. 
Gibbon, P. (2014). Trading Houses During and Since the Great Commodity Boom: Financialization, Productivization or ...? DIIS Working Paper, 2014(12): 134. https://www.diis.dk/files/media/publications/publikationer_2014/wp2014-12.pdf

Global Financial Data. (2020). GFD Database. http://www.globalfinancialdata.com/

Goldthau, A., \& Hughes, L. (2020). Saudi on the Rhine? Explaining the emergence of private governance in the global oil market. Review of International Political Economy, DOI: $10.1080 / 09692290.2020 .1748683$

Greenpeace. (2017). Dirty bankers: How HSBC is financing forest destruction for palm oil. http://www.greenpeace.org/archiveinternational/Global/international/publications/forests/2017/Greenpeace_DirtyBankers_fin al.pdf

Helleiner, E. (2018). Positioning for Stronger Limits? In: E. Helleiner, S. Pagliari \& I. Spagna, eds. Governing the world's biggest market: The politics of derivatives regulation after the 2008 crisis. Oxford: Oxford University Press, 199-225.

Heyman, J. (2015 February 17) Dock workers, shippers face off at the Port of Oakland, San Fransisco Chronicle. https://www.sfchronicle.com/opinion/openforum/article/Dockworkers-shippers-face-off-at-the-Port-of-6086072.php

Hiraga, M. (2018). Financialization in Japanese agri-food regimes: Uncovering the role of sogo-shosha in global soy investment. In H. Bjorkhaug, A. Magnan, G. Lawrence (Eds.), The financialization of agri-food systems: contested transformations (pp.156-175) Routledge.

Isakson, S. R. (2014). Food and finance: The financial transformation of agro-food supply chains. Journal of Peasant Studies, 41(5), 749-775.

Jenkins, H. (2018). History of the funds. Ghost in the Machine, ADM Investor Service International. 2018(4), 14-15. https://www.admisi.com/market-information/the-ghost-inthe-machine/

Kelly, K. (2014). The secret club that runs the world: Inside the fraternity of commodity traders. Penguin.

Kerber, R. (2016 September 6). State Street funds ramp up support for climate-change measures. Reuters. https://uk.reuters.com/article/us-climate-statestreet/state-street-fundsramp-up-support-for-climate-change-measures-idUSKCN11C2HK

Kingsman, J. (2018). 'We know where we are going'. A conversation with Ian McIntosh, CEO of Louis Dreyfus Company. Commodity Conversations. http://commodityconversati ons.com/wordpress2/2018/11/26/we-know-where-we-are-going-a-conversation-with-ianmcintosh-ceo-of-louis-dreyfus-company/

Kingsman, J. (2019). Out of the shadows: The new merchants of grain. Self-published. 
Kollbrunner, T. (2020). We've simply been forgotten. Public Eye. https://stories.publiceye.ch/glencorebolivia/

Krippner, G. R. (2011). Capitalizing on crisis: The political origins of the rise of finance. Harvard University Press.

Kurtz, C. (2018 February 14) Poultry workers charge abuse at Cargill. WMRA. https://www.wmra.org/post/poultry-workers-charge-abuse-cargill\#stream/0

Labban, M. (2014). Against value: Accumulation in the oil industry and the biopolitics of labour under finance. Antipode, 46(2), 477-496.

Lawrence, F. (2011, June 2). The global food crisis: ABCD of food - how the multinationals dominate trade. The Guardian. https://www.theguardian.com/global-development/povertymatters/2011/jun/02/abcd-food-giants-dominate-trade

Lazonick, W., \& O'Sullivan, M. (2000). Maximizing shareholder value: A new ideology for corporate governance. Economy and Society, 29(1), 13-35.

Mader, P., Mertens, D. \& Van der Zwan, N. (2020). Financialization: An introduction. The Routledge international handbook of financialization. Abingdon: Routledge, 1-24.

MacLeod, M., \& Park, J. (2011). Financial activism and global climate change: The rise of investor-driven governance networks. Global Environmental Politics, 11(2), 54-74.

Mason, J. \& Stempel, J. (2012, July 12). Louis Dreyfus sued by trader over cotton squeeze. Reuters. https://uk.reuters.com/article/cotton-manipulation-lawsuit/update-3-louis-dreyfussued-by-trader-over-cotton-squeeze-idUSL2E8I23YS20120702

McMichael, P. (2012). The land grab and corporate food regime restructuring. The Journal of Peasant Studies, 39(3-4), 681-701.

Meyer, G. (2019, September 12). Cargill exits asset management business with CarVal sale. Financial Times. https://www.ft.com/content/e2d64b84-d5a6-11e9-8367-807ebd53ab77

Milberg, W. (2008). Shifting sources and uses of profits: Sustaining US financialization with global value chains. Economy and Society, 37(3), 420-451.

Mooney, A. (2020 October 4). BlackRock criticised over drop in climate votes. Financial Times. https://www.ft.com/content/7a80f33b-a0ed-4dea-b2d3-ce56381f4084

Moore, J.W. (2015). Capitalism in the web of life: Ecology and the accumulation of capital. Verso Books.

Morgan, D. (1979). Merchants of grain: The power and profits of the five giant companies at the center of the world's food supply. Viking Press.

Murphy, S., Burch, D., \& Clapp, J. (2012). Cereal secrets. The world's largest grain traders and global agriculture. Oxfam Research Reports. https://www-cdn.oxfam.org/s3fspublic/file_attachments/rr-cereal-secrets-grain-traders-agriculture-30082012-en_4.pdf 
Neville, K.J. (2020). Shadows of divestment: The complications of diverting fossil fuel finance. Global Environmental Politics, 20(2), 3-11.

Neville, K.J., Cook, J., Baka, J., Bakker, K., \& Weinthal, E.S. (2019). Can shareholder advocacy shape energy governance? The case of the US antifracking movement. Review of International Political Economy, 26(1), 104-133.

Newman, S.A. (2009). Financialization and changes in the social relations along commodity chains: The case of coffee. Review of Radical Political Economics, 41(4), 539-559.

Nitzan, J., \& Bichler, S. (2009). Capital as power: A study of order and creorder. Routledge.

Omarova, S.T. (2013). The merchants of Wall Street: Banking, commerce, and commodities. Minnesota Law Review, 98, 265-355.

Orhangazi, Ö. (2008). Financialisation and capital accumulation in the non-financial corporate sector: A theoretical and empirical investigation on the US economy: 1973-2003. Cambridge Journal of Economics, 32(6), 863-886.

Orbis. (2020). Orbis Database - Bureau van Dijk https://www.bvdinfo.com/en-gb/ourproducts/data/international/orbis?gclid=Cj0KCQjw2or8BRCNARIsAC_ppyYtd4TZ6x7D yyCpALAkPP9kQF-22vu2OzgE8W3TVBGjSv-qiU6NXfoaAvWAEALw_wcB

Oxfam. (2012a). Review of the markets in financial instruments directive, completed questionnaire.

http://www.europarl.europa.eu/document/activities/cont/201202/20120222ATT38996/201 20222ATT38996EN.pdf

Oxfam. (2012b). Oxfam reaction to Glencore director saying the US drought is good for business. https://www.oxfam.org.uk/media-centre/press-releases/2012/08/oxfam-reactionto-glencore-comment-that-us-drought-is-good-for-business

Pagliari, S. (2018). The second half: interest group conflicts and coalitions in the implementation of the Dodd-Frank Act derivatives rules. In: E. Helleiner, S. Pagliari \& I. Spagna, eds. Governing the world's biggest market: The politics of derivatives regulation after the 2008 crisis. Oxford: Oxford University Press, 137-167.

Pagliari, S., \& Young, K.L. (2014). Leveraged interests: Financial industry power and the role of private sector coalitions. Review of International Political Economy, 21(3), 575-610.

Parker, R., Cox, S., \& Thompson, P. (2018). Financialization and value-based control: Lessons from the Australian mining supply chain. Economic Geography, 94(1), 49-67.

Pirrong, C. (2014). The economics of commodity trading firms. Trafigura. http://www.bauer.uh.edu/centers/uhgemi/casedocs/The-Economics-of-CommodityTrading-Firms-2.pdf

Prosser, M. (2011, February 11). Shell sells African businesses for \$1bn. Financial Times. https://www.ft.com/content/be31fe62-3d99-11e0-ae2a-00144feabdc0 
Proxy Insight. (2020). Proxy Insight Database. https://www.proxyinsight.com/

Rabinovich, J. (2019). The financialization of the non-financial corporation. A critique to the financial turn of accumulation hypothesis. Metroeconomica, 70(4), 738-775.

Reuters, (2017). Louis Dreyfus to wind down Edesia commodity funds in overhaul. Reuters. https://www.reuters.com/article/us-hedgefunds-louisdreyfus-edesia/louis-dreyfus-to-winddown-edesia-commodity-funds-in-overhaul-idUSKCN1C11XO

Salerno, T. (2017). Cargill's corporate growth in times of crises: How agro-commodity traders are increasing profits in the midst of volatility. Agriculture and Human Values, 34(1), 211222.

Schleifer, P., \& Sun, Y. (2018). Emerging markets and private governance: The political economy of sustainable palm oil in China and India. Review of International Political Economy, 25(2), 190-214.

Schneyer, J. (2011, October 20). Corrected: Commodity traders: The trillion dollar club. Reuters. https://www.reuters.com/article/us-commodities-houses/corrected-commoditytraders-the-trillion-dollar-club-idUSTRE79R4S320111028

Seddon, J. (2020). Merchants against the bankers: The financialization of a commodity market. Review of International Political Economy, 27(3), 525-555.

Sheppard, D., \& Hume, N. (2017 March 26). Oil trading surge strengthens grip of big commodity houses. Financial Times. https://www.ft.com/content/1f12b950-1085-11e7a88c-50ba212dce4d

Singh, S. \& Rowling, R. (2015, April 8). Bunge plans to 'significantly' reduce assetmanagement business. Bloomberg. https:/www.bloomberg.com/news/articles/2015-0408/bunge-plans-to-significantly-reduce-asset-management-business

Soener, M. (2020). Did the 'real' economy turn financial? Mapping the contours of financialisation in the non-financial corporate sector. New Political Economy. DOI: 10.1080/13563467.2020.1858775. 1-15.

Sporre, G., Clifford, R., \& De Buyer, G. 2011. The value in volatility: Initiating with a buy. Deutsche Bank Global Market Research. pp.1-130.

Staritz, C., Newman, S., Tröster, B., \& Plank, L. (2018). Financialization and global commodity chains: Distributional implications for cotton in Sub-Saharan Africa. Development and Change, 49(3), 815-842.

Steger, M. (2005). Ideologies of globalization. Journal of Political Ideologies. 10(1), 11-30.

Steinweg, T., De Wilde, J. \& Piotrowski, M. (2018). ADM: Matopiba sourcing could link company to deforestation. Chain Reaction Research. https:/chainreactionresearch.com/report/adm-matopiba-sourcing-could-link-company-todeforestation/ 
Stevens, P. (2016). International oil companies: The death of the old business model, Chatham House Research Paper, London, UK. http://www.biee.org/wpcms/wpcontent/uploads/International-oil-companies-Paul-Stevens.pdf

Stockhammer, E. (2004). Financialisation and the slowdown of accumulation. Cambridge Journal of Economics, 28(5), 719-741.

Stringer, L. (2014, August 22). ConAgra's palm oil commitment: Saving forests and reducing greenhouse gases. The Guardian. https:/www.theguardian.com/sustainablebusiness/2014/aug/22/conagra-palm-oil-deforestation-greenhouse-gases-supply-chain

Terazono, E. (2015, August 6). Poor returns see investors lose interest in commodity hedge funds. Financial Times. https://www.ft.com/content/f48e894e-3a92-11e5-bbd1b37bc06f590c

The Economist (2014, September 6). End-to-end game, https://www.economist.com/financeand-economics/2014/09/06/end-to-end-game

Thomson Reuters Eikon (2020). Thomson Reuters Eikon Database. https://eikon.thomson reuters.com/index.html

Tomas, J.P. (2018, June 25). General strike paralyses Argentina's grain exports, crushers. AgriCensus. https://www.agricensus.com/Article/General-strike-paralyses-Argentina-sgrain-exports-crushers-2239.html

Tomas, J.P. (2019, September 5). Argentine crush workers launch strike action over wage demands. https://www.agricensus.com/Article/Argentine-crush-workers-launch-strikeaction-over-wage-demands-8332.html

Trafigura (2013) Puma energy becomes largest independent in Australia. Press release. https:/www.trafigura.com/press-releases/puma-energy-becomes-largest-independent-inaustralia

Van der Zwan, N. (2014). Making sense of financialization. Socio-Economic Review, 12(1), 99-129.

Zhdannikov, D. \& Antonioli, S. (2014, October 3). JP Morgan sells commodity arm to Mercuria for $\$ 800$ million. Reuters. https://uk.reuters.com/article/us-mercuria-jpmorgan/jpmorgan-sells-commodity-arm-to-mercuria-for-800-million-sources-

idUKKCNOHS1JA20141003 


\section{Appendix}

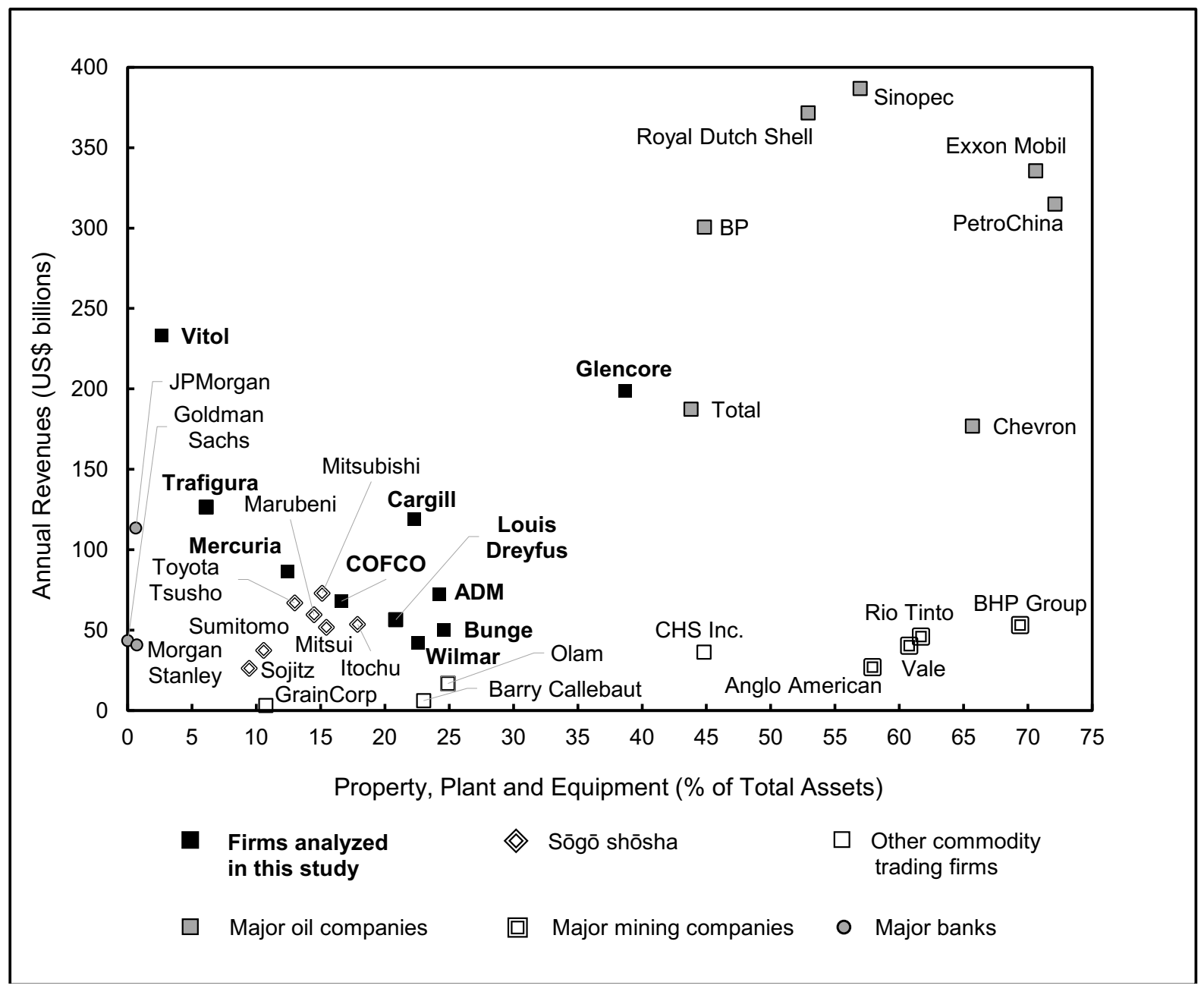

Figure A1. Average Physical Asset Intensity and Revenues of Firms with Major Commodity Trading Operations, 2010-19

Source: Bloomberg Professional (2020), Orbis (2020) and Thomson Reuters Eikon (2020)

Note: The asset data for Vitol only covers the period 2010-2016. The revenue and asset data for Mercuria only cover the periods 2012-19 and 2012-17 respectively. 

zero to the variable?

\begin{tabular}{ll}
\hline Assets - Total (at) & Exclude \\
Debt in Current Liabilities (dlc) & Exclude \\
Dividends - Total (dvt) & Impute Zero \\
Equity in Earnings - Unconsolidated Subsidiaries (esub) & Impute Zero \\
Income Taxes - Current (txc) & Exclude \\
Interest and Related Expense - Total (xint) & Exclude \\
Interest and Related Income - Total (idit) & Impute Zero \\
Long-Term Debt (dltt) & Exclude \\
Operating Profit - Segment (ops) & Impute Zero \\
Plant, Property and Equipment - Total (ppent) & Exclude \\
Purchase of Common and Preferred Stock (prstkc) & Impute Zero \\
Revenue - Total (revt) & Exclude \\
\hline
\end{tabular}

\section{Table A1. Description of Variables and Filtering Procedures for Compustat 1000}

Note: The Compustat 1000 represents the 1000 largest non-financial firms headquartered in the US as ranked by net income. Our dataset for the Compustat 1000 therefore comprises 30,000 firm-year observations over the period from 1990 to 2019. We have followed a strict filtering procedure that aims to eliminate problematic entries while maximizing the representativeness of the Compustat 1000 firms. To filter out financial firms, we have excluded all corporations with a Standard Industrial Classification (SIC) code starting with ' 6 '. To filter out all foreign corporations we have only included firms with an ISO country code for their headquarters (LOC) of 'USA'. To remove problematic entries, we have excised all observations for a firm in any given year that records negative values for assets or revenues. Furthermore, we have dropped all firm-year observations with missing data for any of our variables other than dividend payments, interest income, dividend income, share repurchases and segment operating profit. All data are taken from Compustat North America, other than the segment data which are taken from Compustat Segments. To collect data on financial divisions of non-financial firms we have included only data for segments which have a segment standard industrial classification (SICS1) code starting with ' 6 ', and then matched these financial division data with consolidated data taken from Compustat North America. Overall, of the 1000 firms included annually in our Compustat 1000 proxy, an average of 87 firms have reported data on financial segment operating profits for any given year. This reached a maximum level of 101 firms in 2001 and 2004, and a minimum level of 65 firms in 1997. 


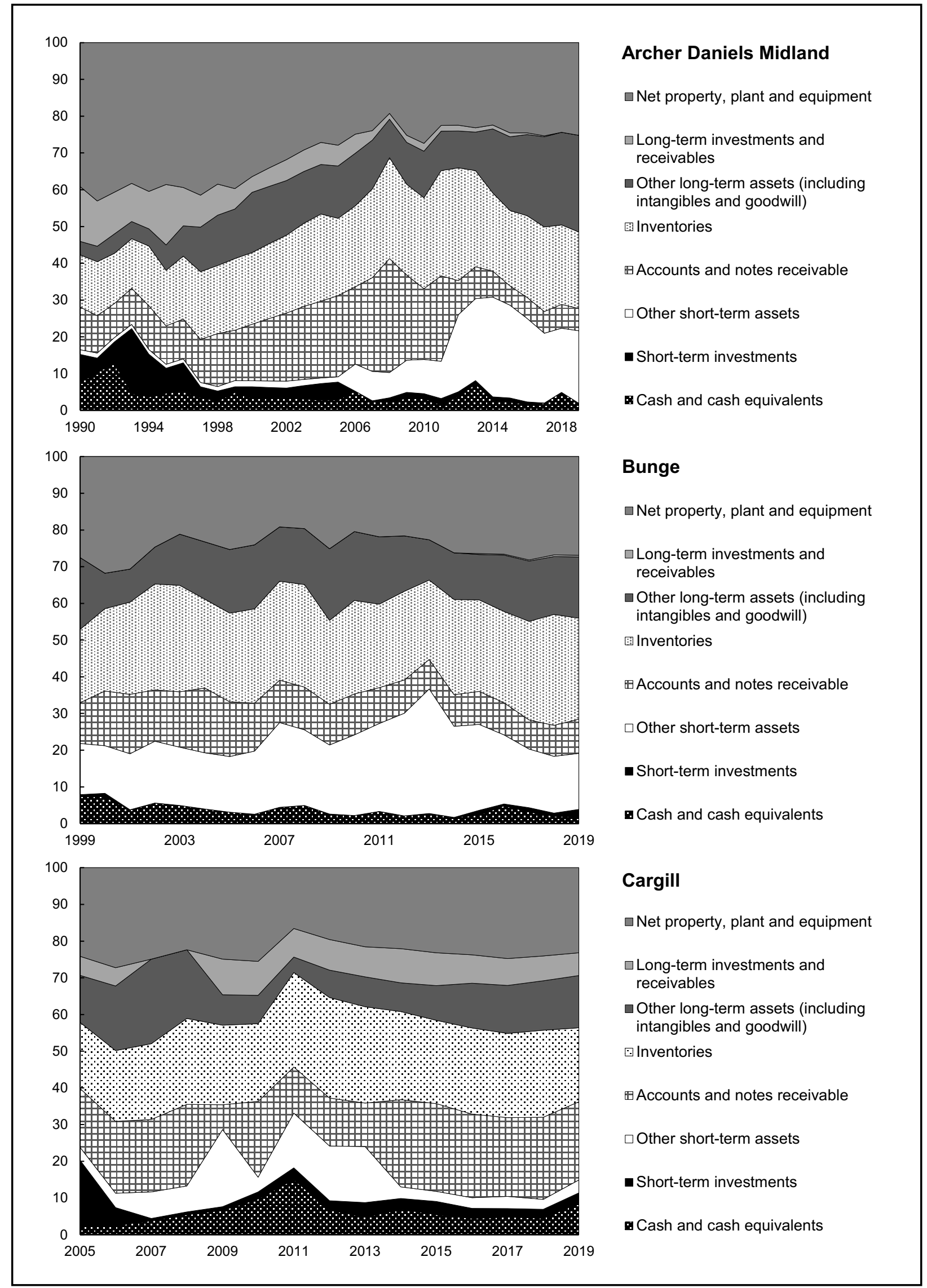




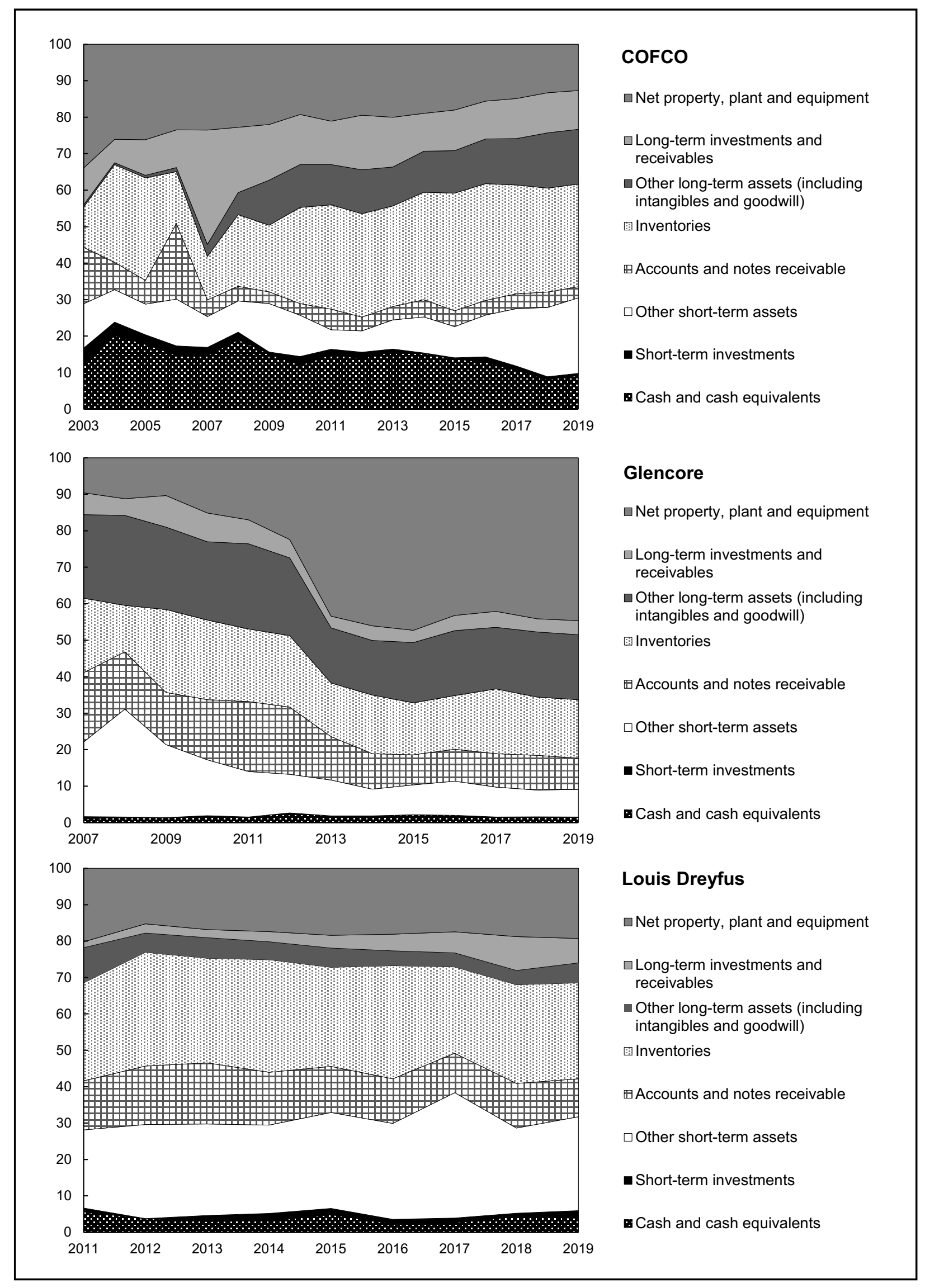

Figure A2. Asset Structures of the Commodity Trading Firms (continued...) 


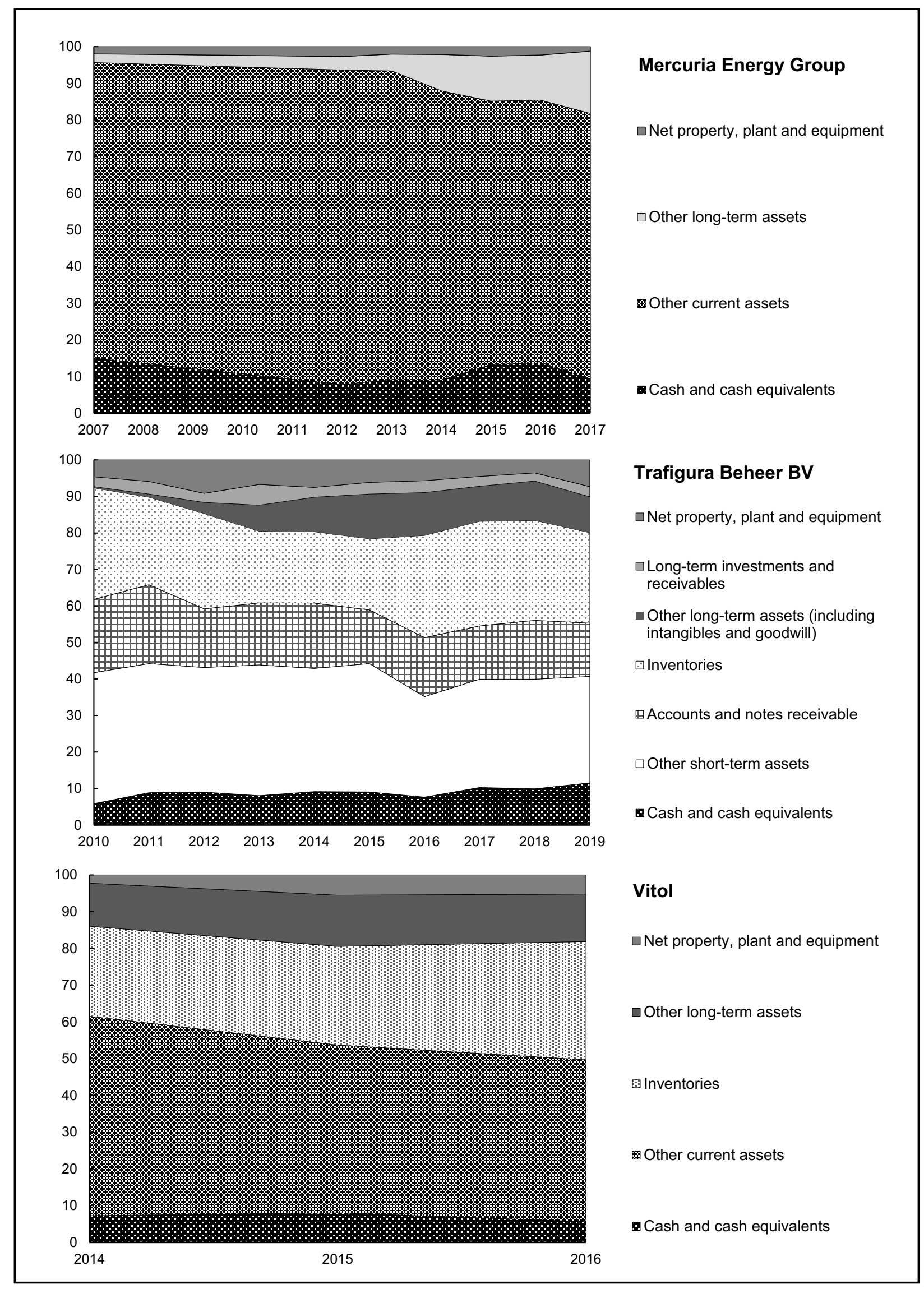

Figure A2. Asset Structures of the Commodity Trading Firms (continued...) 


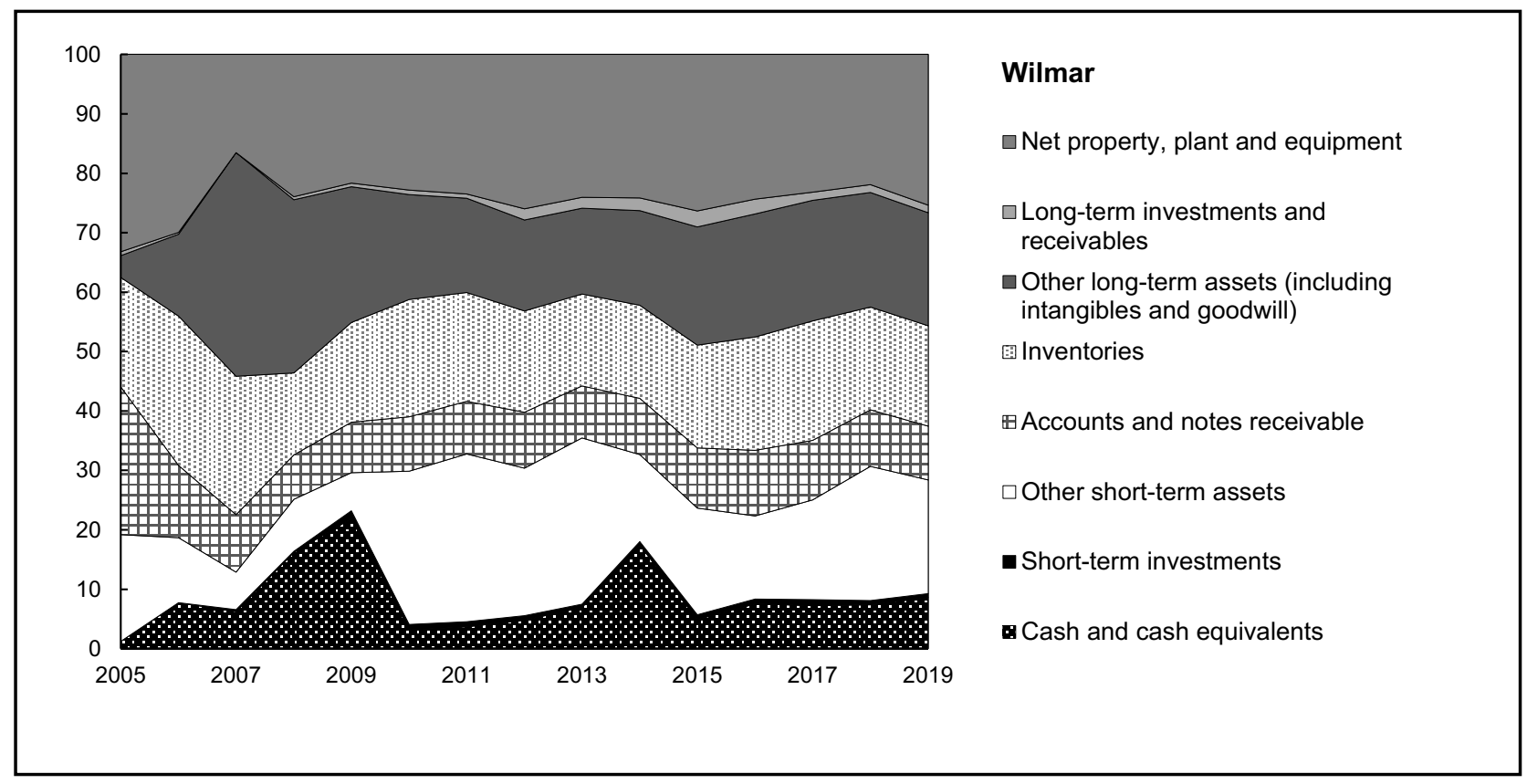

Figure A2. Asset Structures of the Commodity Trading Firms

Source: Bloomberg Professional (2020) and Orbis (2020) 


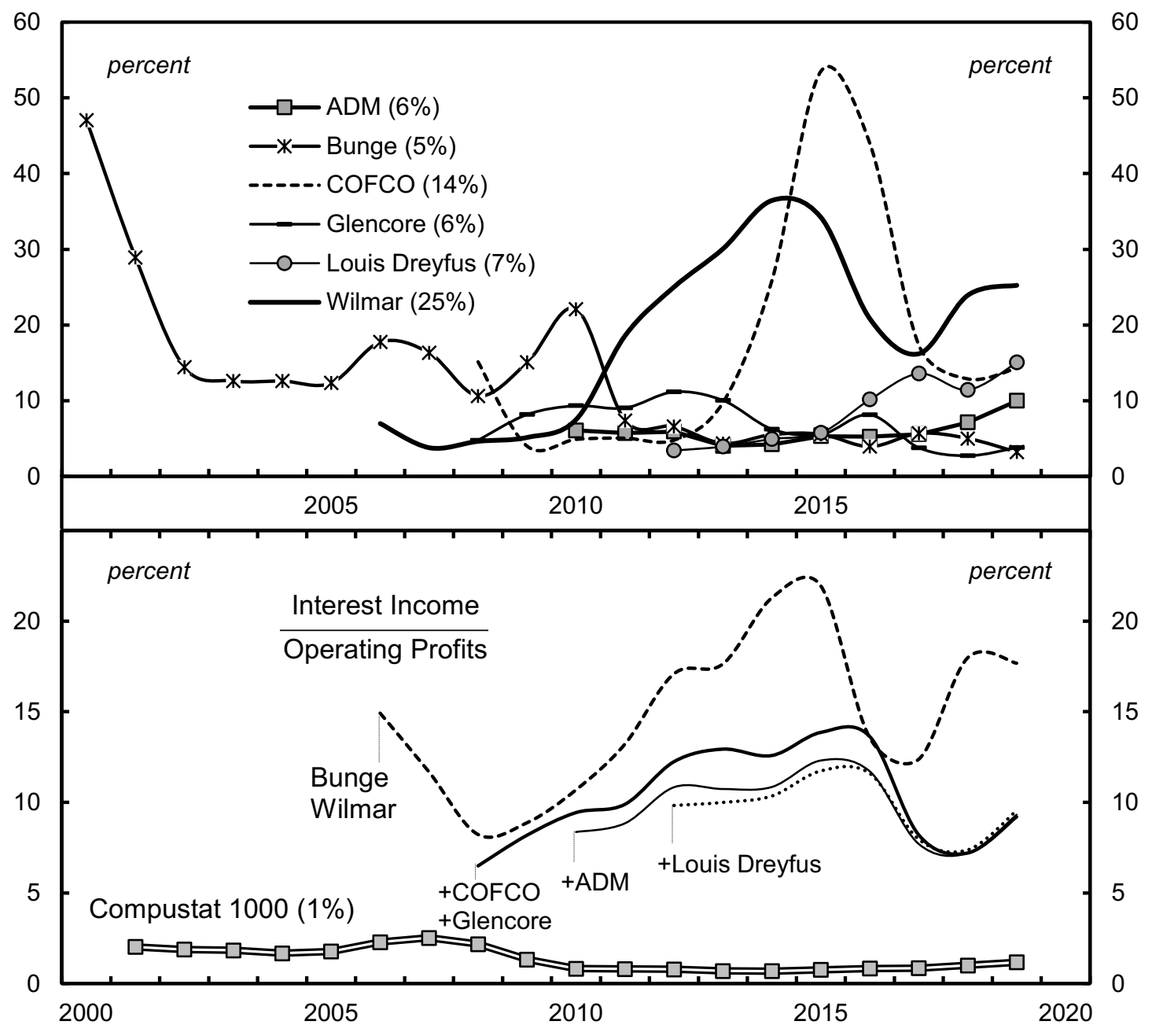

Figure A3. Interest Income of Commodity Trading Firms

Source: Bloomberg Professional (2020) and Compustat (2020)

Note: Figures in parentheses are the average values for 2010-2019. Series data are smoothed to 2-year moving averages. Operating profits for Compustat 1000 is defined simply as the sum of net income, interest expenses and tax payments. Series codes for Compustat 1000: idit, ni, xint and txc. 


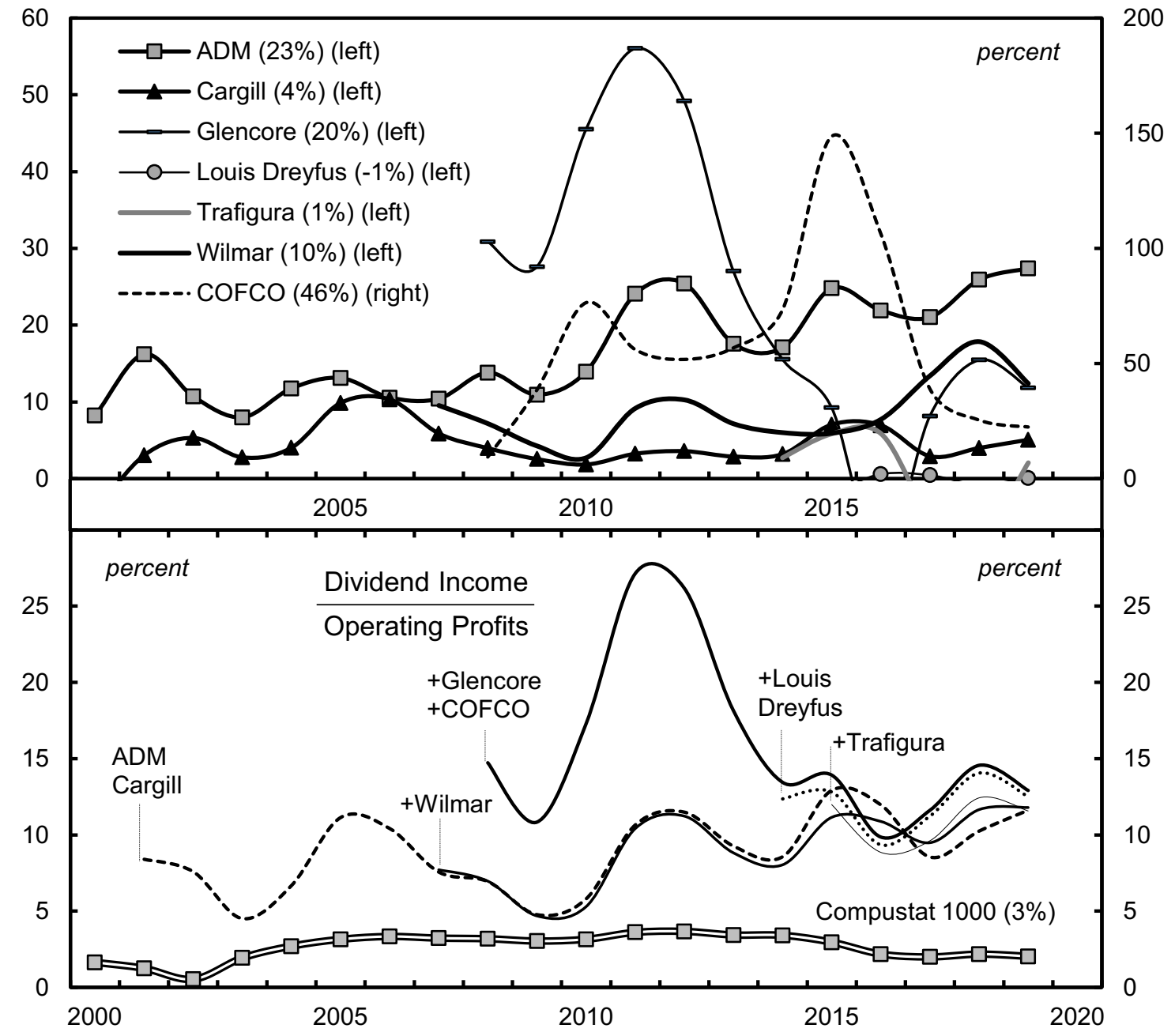

Figure A4. Dividend Income of Commodity Trading Firms

Source: Bloomberg Professional (2020) and Compustat (2020)

Note: Figures in parentheses are the average values for 2010-2019. Series data are smoothed to 2-year moving averages. Operating profits for Compustat 1000 is defined simply as the sum of net income, interest expenses and tax payments. Series codes for Compustat 1000: esub, ni, xint and txc. 


\begin{tabular}{l|rrrr}
\hline & BlackRock & Vanguard & State Street & Average \\
\hline $\begin{array}{l}\text { No. of management resolutions on approving } \\
\text { dividends and stock buybacks in firms in } \\
\text { which asset management company has } \\
\text { equity }\end{array}$ & 6243 & 7437 & 7652 & 7111 \\
$\quad \begin{array}{l}\text { Percentage of these resolutions that } \\
\text { asset management company } \\
\text { favoured in vote }\end{array}$ & 93.5 & 96.9 & 96.8 & 95.9 \\
$\begin{array}{l}\text { Percentage of these resolutions } \\
\text { gaining a simple majority }\end{array}$ & 99.9 & 99.9 & 99.9 & 99.9 \\
$\begin{array}{l}\text { Percentage of these resolutions } \\
\text { gaining a simple majority that asset } \\
\text { management firm opposed }\end{array}$ & 1.3 & 0.3 & 1.9 & 1.2 \\
\hline $\begin{array}{l}\text { No. of shareholder resolutions on improving } \\
\text { environmental and social governance in } \\
\text { firms in which asset management company } \\
\text { has equity }\end{array}$ & 560 & 408 & 416 & 455 \\
$\begin{array}{l}\text { Percentage of these resolutions that } \\
\text { asset management company } \\
\text { favoured in vote }\end{array}$ & 6.4 & 6.6 & 18.3 & 10.7 \\
$\begin{array}{l}\text { Percentage of these resolutions } \\
\text { gaining a simple majority }\end{array}$ & & & & \\
$\begin{array}{l}\text { Percentage of these resolutions } \\
\text { gaining a simple majority that asset } \\
\text { management firm opposed }\end{array}$ & 5.9 & 5.6 & 5.5 & 5.7 \\
\hline
\end{tabular}

Table A2. The Three Major Asset Management Firms' Voting Behaviour for Resolutions held at Commodity Firms in which they hold Equity, 2014-2019

Source: Proxy Insight (2020)

Note: Commodity firms here are defined as those firms identified by Proxy Insight as belonging to the following sectors: basic materials, consumer cyclical, consumer defensive and energy. Environmental and social governance resolutions are defined as those categorized by Proxy Insight as the following resolution types: corporate social responsibility, energy, environmental, human rights, social and sustainability. Averages are weighted according to the number of resolutions that the asset management firms were able to vote on. 


\begin{tabular}{rrrrrrr}
\hline & \multicolumn{2}{c}{ ADM } & \multicolumn{2}{c}{ Bunge } & \multicolumn{2}{c}{ Trafigura } \\
\hline & $\begin{array}{r}\text { Size of } \\
\text { program } \\
\text { (US\$ bn) }\end{array}$ & $\begin{array}{r}\text { Percentage of } \\
\text { assets taken off } \\
\text { balance sheet }\end{array}$ & $\begin{array}{r}\text { Size of } \\
\text { program } \\
\text { (US\$ bn) }\end{array}$ & $\begin{array}{r}\text { Percentage of } \\
\text { assets taken off } \\
\text { balance sheet }\end{array}$ & $\begin{array}{r}\text { Size of } \\
\text { program } \\
\text { (US\$ bn) }\end{array}$ & $\begin{array}{r}\text { Percentage of } \\
\text { assets taken off } \\
\text { balance sheet }\end{array}$ \\
\hline $2005-09$ & - & - & 0.32 & $1.8 \%$ & 0.65 & $4.7 \%$ \\
$2010-14$ & 1.12 & $4.2 \%$ & 0.68 & $2.3 \%$ & 2.32 & $6.3 \%$ \\
$2015-19$ & 1.74 & $4.1 \%$ & 0.71 & $3.7 \%$ & 3.05 & $6.1 \%$ \\
\hline
\end{tabular}

Table A3. Receivables Securitization Programmes of Commodity Trading Firms

Source: Bloomberg Professional (2020) 